Fryer, P., Wheat, C.G., Williams, T., and the Expedition 366 Scientists

Proceedings of the International Ocean Discovery Program Volume 366

publications.iodp.org

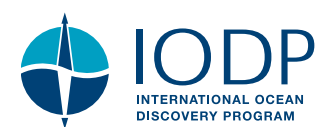

\title{
Contents
}

\section{Expedition 366 summary ${ }^{1}$}

Check for updates

P. Fryer, C.G. Wheat, T. Williams, E. Albers, B. Bekins, B.P.R. Debret, J. Deng,

Y. Dong, P. Eickenbusch, E.A. Frery, Y. Ichiyama, K. Johnson, R.M. Johnston,

R.T. Kevorkian, W. Kurz, V. Magalhaes, S.S. Mantovanelli, W. Menapace,

C.D. Menzies, K. Michibayashi, C.L. Moyer, K.K. Mullane, J.-W. Park, R.E. Price,

J.G. Ryan, J.W. Shervais, O.J. Sissmann, S. Suzuki, K. Takai, B. Walter, and

R. Zhang ${ }^{2}$

Keywords: International Ocean Discovery Program, IODP, JOIDES Resolution, Expedition 366, Site 1200, Site U1491, Site U1492, Site U1493, Site U1494, Site U1495, Site U1496, Site U1497, Site U1498, Mariana, Asùt Tesoru Seamount, Conical Seamount, Fantangisña Seamount, South Chamorro Seamount, Yinazao Seamount, Cretaceous seamount, subduction, subduction channel, forearc, seismogenic zone, mud volcano, fluid discharge, serpentinite, carbonate, harzburgite, clasts, ultramafic rock, breccia, gypsum, mudstone, chert, reef limestone, volcanic ash, guyot, CORK, CORK-Lite, screened casing

\section{Abstract}

Geologic processes at convergent plate margins control geochemical cycling, seismicity, and deep biosphere activity in subduction zones and suprasubduction zone lithosphere. International Ocean Discovery Program Expedition 366 was designed to address the nature of these processes in the shallow to intermediate depth of the Mariana subduction channel. Although no technology is available to permit direct sampling of the subduction channel of an intraoceanic convergent margin at depths up to $19 \mathrm{~km}$, the Mariana forearc region (between the trench and the active volcanic arc) provides a means to access materials from this zone.

Active conduits, resulting from fractures in the forearc, are prompted by along- and across-strike extension that allows slab-derived fluids and materials to ascend to the seafloor along associated faults, resulting in the formation of serpentinite mud volcanoes. Serpentinite mud volcanoes of the Mariana forearc are the largest mud volcanoes on Earth. Their positions adjacent to or atop fault scarps on the forearc are likely related to the regional extension and vertical tectonic deformation in the forearc. Serpentinite mudflows at these volcanoes include serpentinized forearc mantle clasts, crustal and subducted Pacific plate materials, a matrix of serpentinite muds, and deep-sourced formation fluid. Mud volcanism on the Mariana forearc occurs within $100 \mathrm{~km}$ of the trench, representing a range of depths and temperatures to the downgoing plate and the subduction channel. These processes have likely been active for tens of millions of years at the Mariana forearc and for billions of years on Earth.
At least 19 active serpentinite mud volcanoes have been located in the Mariana forearc. Two of these mud volcanoes are Conical and South Chamorro Seamounts, which are the farthest from the Mariana Trench at 86 and $78 \mathrm{~km}$, respectively. Both seamounts were cored during Ocean Drilling Program Legs 125 and 195, respectively. Data from these two seamounts represent deeper, warmer examples of the continuum of slab-derived materials as the Pacific plate subducts, providing a snapshot of how slab subduction affects fluid release, the composition of ascending fluids, mantle hydration, and the metamorphic paragenesis of subducted oceanic lithosphere. Data from the study of these two mud volcanoes constrain the pressure, temperature, and composition of fluids and materials within the subduction channel at depths of up to $19 \mathrm{~km}$. Understanding such processes is necessary for elucidating factors that control seismicity in convergent margins, tectonic and magma genesis processes in the volcanic arc and backarc areas, fluid and material fluxes, and the nature and variability of environmental conditions that impact subseafloor microbial communities.

Expedition 366 focused on data collection from cores recovered from three serpentinite mud volcanoes that define a continuum of subduction-channel processes to compare with results from drilling at the two previously cored serpentinite mud volcanoes and with previously collected gravity, piston, and remotely operated vehicle push cores across the trench-proximal forearc. Three serpentinite mud volcanoes (Yinazao, Fantangisña, and Asùt Tesoro) were chosen at distances 55 to $72 \mathrm{~km}$ from the Mariana Trench. Cores were recovered from active sites of eruption on their summit regions and on the flanks where ancient flows are overlain by more recent ones.

\footnotetext{
1 Fryer, P., Wheat, C.G., Williams, T., Albers, E. Bekins, B., Debret, B.P.R., Deng, J., Dong, Y., Eickenbusch, P., Frery, E.A., Ichiyama, Y., Johnson, K., Johnston, R.M., Kevorkian, R.T., Kurz, W. Magalhaes, V., Mantovanelli, S.S., Menapace, W., Menzies, C.D., Michibayashi, K., Moyer, C.L., Mullane, K.K., Park, J.-W., Price, R.E., Ryan, J.G., Shervais, J.W., Sissmann, O.J., Suzuki, S., Takai, K., Walter, B., and Zhang, R., 2018. Expedition 366 summary. In Fryer, P., Wheat, C.G., Williams, T., and the Expedition 366 Scientists, Mariana Convergent Margin and South Chamorro Seamount. Proceedings of the International Ocean Discovery Program, 366: College Station, TX (International Ocean Discovery Program). https://doi.org/10.14379/iodp.proc.366.101.2018

2 Expedition 366 Scientists' addresses.

MS 366-101: Published 7 February 2018

This work is distributed under the Creative Commons Attribution 4.0 International (CC BY 4.0) license. (cc))B
} 
Recovered materials show the effects of dynamic processes that are active at these sites, bringing a range of materials to the seafloor, including materials from the crust of the Pacific plate, most notably subducted seamounts (even corals). Most of the recovered material consists of serpentinite mud containing lithic clasts, which are derived from the underlying forearc crust and mantle and the subducting Pacific plate. A thin cover of pelagic sediment was recovered at many Expedition 366 sites, and at Site U1498 we cored through distal serpentinite mudflows and into the underlying pelagic sediment and volcanic ash deposits. Recovered serpentinized ultramafic rocks and mudflow matrix materials are largely uniform in major element composition, spanning a limited range in $\mathrm{SiO}_{2}$, $\mathrm{MgO}$, and $\mathrm{Fe}_{2} \mathrm{O}_{3}$ compositions. However, variation in trace element composition reflects interstitial water composition, which differs as a function of the temperature and pressure of the underlying subduction channel. Dissolved gases $\mathrm{H}_{2}, \mathrm{CH}_{4}$, and $\mathrm{C}_{2} \mathrm{H}_{6}$ are highest at the site farthest from the trench, which also has the most active fluid discharge of the Expedition 366 serpentinite mud volcanoes. These dissolved gases and their active discharge from depth likely support active microbial communities, which were the focus of indepth subsampling and preservation for shore-based analytical and culturing procedures. The effects of fluid discharge were also registered in the porosity and gamma ray attenuation density data indicated by higher than expected values at some of the summit sites. These higher values are consistent with overpressured fluids that slow compaction of serpentinite mud deposits. In contrast, flank sites have significantly greater decreases in porosity with depth, suggesting that processes in addition to compaction are required to achieve the observed data. Thermal measurements reveal higher heat flow values on the flanks $\left(\sim 31 \mathrm{~mW} / \mathrm{m}^{2}\right)$ than on the summits $\left(\sim 17 \mathrm{~mW} / \mathrm{m}^{2}\right)$ of the seamounts. The new $2 \mathrm{G}$ Enterprises superconducting rock magnetometer (liquid helium free) revealed relatively high values of both magnetization and bulk magnetic susceptibility of discrete samples related to ultramafic rocks, particularly dunite. Magnetite, a product of serpentinization, and authigenic carbonates were observed in the mudflow matrix materials.

In addition to coring operations, Expedition 366 focused on the deployment and remediation of borehole casings for future observatories and set the framework for in situ experimentation. Borehole work commenced at South Chamorro Seamount, where the original-style CORK was partially removed. Work then continued at each of the three summit sites following coring operations. Cased boreholes with at least three joints of screened casing were deployed, and a plug of cement was placed at the bottom of each hole. Water samples were collected from two of the three boreholes, revealing significant inputs of formation fluids. This suggests that each of the boreholes tapped a hydrologic zone, making these boreholes suitable for experimentation with the future deployment of a CORK-Lite.

\section{Background}

Geologic processes at convergent plate margins affect geochemical cycling and fluxes, seismicity and natural hazards, crustal and mantle evolution and mixing, and biosphere activity and population dynamics in subduction zones. To constrain these processes, inputs and outputs must be quantified. Quantifying inputs into a convergent plate margin is accomplished by sampling the downgoing plate prior to subduction to provide a geochemical, physical, and mechanical reference. The study of the output in terms of magma and volatiles in volcanic arcs and in backarc basin settings constrains processes that occur deep within the subduction zone, but such studies of subduction systems are incomplete, lacking an understanding of processes that occur between the time the subducting plate enters the trench and the time it reaches the zone of magma genesis beneath the arc. The Mariana convergent system provides natural windows into this zone.

The Mariana convergent system is a nonaccretionary-type convergent plate margin (Uyeda and Kanamori, 1979). Here, fluids and materials rise from the subducted Pacific plate within long-lived permeable pathways through the overlying Philippine plate. Such pathways are maintained with across- and along-strike extension (Fryer and Salisbury, 2006). Vertical tectonic deformation is another potential process that shapes fault patterns in the forearc. Vertical deformation occurs when Cretaceous Pacific plate guyots are subducted. In contrast, the zone between the trench and the region of arc magmagenesis is not accessible in accretionary forearcs. Here, deep-sourced fluids ascend through imbricate fault systems and splays in a thick prism of the accreted sediments. Transit of deepsourced fluids through the prism results in reactions with a compositionally heterogeneous package of sediments, obfuscating the composition of the deep-sourced fluid. Thus, the Mariana forearc region is unique in the world today in that it provides direct access to deep-sourced fluids and material from the subduction channel and suprasubduction zone via active serpentinite mud volcanism. Furthermore, ascending deep-sourced fluids with elevated $\mathrm{pH}$, methane, and hydrogen concentrations relative to seawater support subsurface microbial communities. Such fluids vent at summit seeps, often supporting megafaunal communities (Fryer, 2012; Ohara et al., 2010).

Therefore, to study processes in the Mariana forearc we chose four active serpentinite mud volcanoes (Yinazao, Fantangisña, Asùt Tesoro, and South Chamorro) for investigation during Expedition 366 (Figure F1; Table T1). Operations included coring at summit and flank sites on Yinazao, Fantangisña, and Asùt Tesoro Seamounts; deploying a screened casing for future borehole experiments on the summits of each; and revitalizing the borehole observatory (CORK) at South Chamorro Seamount (Ocean Drilling Program [ODP] Site 1200).

Yinazao Seamount (informally called Blue Moon Seamount) lies on the eastern edge of a forearc graben about $55 \mathrm{~km}$ from the Mariana Trench axis (Figure F1; Table T1). Of the three mud volcanoes cored during the expedition, Yinazao Seamount is the closest to the trench, and the subducting slab lies approximately $13 \mathrm{~km}$ below its summit (Oakley et al., 2007, 2008). Like the many other serpentinite mud volcanoes that populate the southern half of the Mariana forearc, Yinazao Seamount is situated along a zone of weakness in the overriding plate's lithosphere. The fault trend that controlled the growth of the edifice has a northeast-southwest trend and intersects a northwest-southeast trend immediately south.

A primary feature of the summit of Yinazao Seamount is a fault scarp with a maximum throw of about $80 \mathrm{~m}$ that is colinear with the northeast-southwest fault trend. The eastern half of the summit is shallower, and the overall morphology of the summit suggests a right-lateral motion on a fault with dip-slip to the northwest. The offset on the fault is apparently a combination of footwall uplift (eastern block) and downdrop of the hanging wall to the northwest (western block). This deformation may have directed the egress of rising fluids to the southwest edge of the summit area where a spring was located. Systematic variation in interstitial water composition from serpentinite mud piston cores collected from the research vessel (R/V) Thomas G. Thompson in 2003 confirmed the 
Figure F1. Location map of Sites U1491-U1498 and 1200 on South Chamorro Seamount.

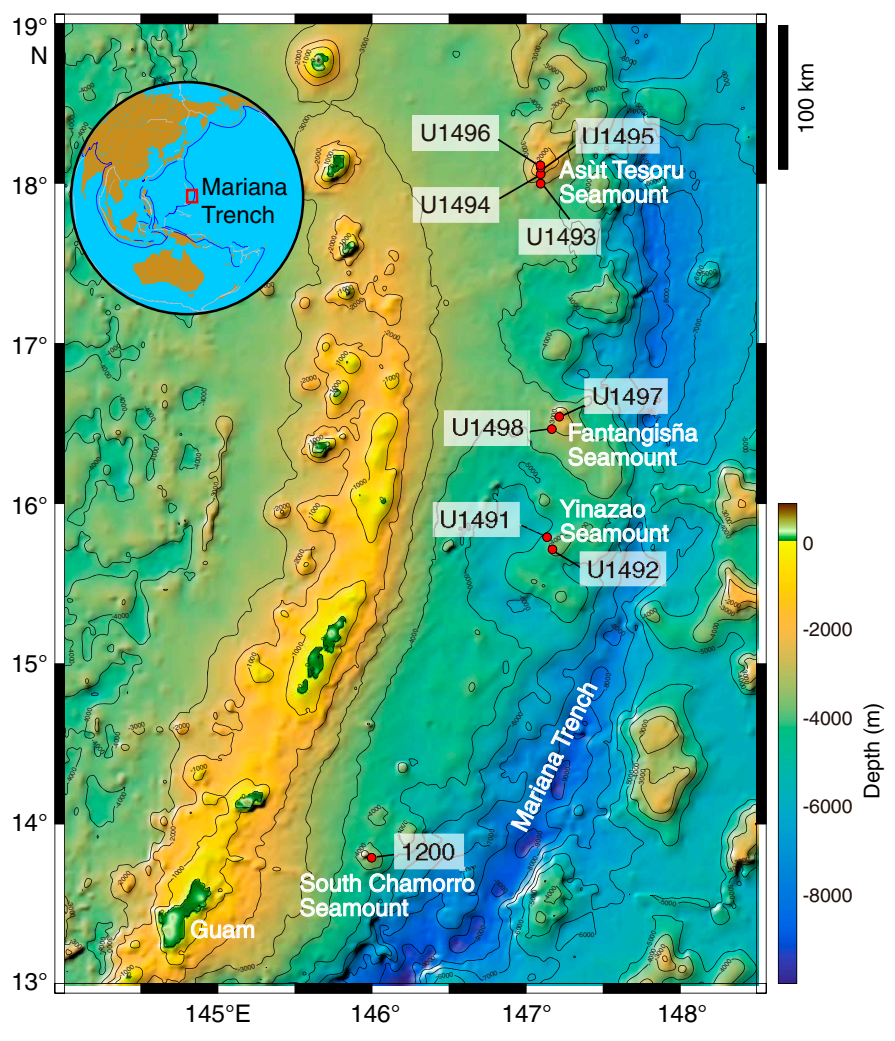

Table T1. Critical parameters of the deep-sourced fluid from five Mariana serpentinite mud volcanoes. Depth-to-slab was determined by seismic reflection profile for Yinazao, Fantangisña, and Asùt Tesoro Seamounts (Oakley et al., 2007, 2008; Oakley, 2008), and by equilibrium mineral assemblages in metamafic clasts for South Chamorro and Conical Seamounts (Maekawa et al., 1993; Fryer et al., 2006; Gharib, 2006). Distance to trench and temperature of slab from Hulme et al. (2010). Depth-to-slab measurements for Yinazao, Fantangisna, and Asùt Tesoro from Oakley et al. (2008) and Oakley (2008). Depth-to-slab measurements for South Chamorro and Conical are extrapolation estimates (see text). Interstitial water measurements from Expedition 366, Mottl et al. (2003, 1992), Mottl (2004), and Hulme et al. (2010). Download table in CSV format.

\begin{tabular}{lccccc}
\hline \multicolumn{1}{c}{ Measurement } & Yinazao & Fantangisña & $\begin{array}{c}\text { Asùt } \\
\text { Tesoro }\end{array}$ & $\begin{array}{c}\text { South } \\
\text { Chamorro }\end{array}$ & Conical \\
\hline Distance to trench $(\mathrm{km})$ & 55 & 62 & 72 & 78 & 86 \\
Depth-to-slab $(\mathrm{km})$ & 13 & 14 & 18 & 18 & 19 \\
Temperature of slab $\left({ }^{\circ} \mathrm{C}\right)$ & $\sim 80$ & $\sim 150$ & $\sim 250$ & $250-350$ & $250-350$ \\
Interstitial water pH & 11.2 & 11.0 & 12.5 & 12.5 & 12.5 \\
Interstitial water $\mathrm{Ca}(\mathrm{mM})$ & 64 & 90 & 0.1 & 0.3 & 1 \\
Interstitial water $\mathrm{K}(\mathrm{mM})$ & $\sim 1$ & 5 & 14 & 19 & 15 \\
\hline
\end{tabular}

presence of fluid discharge at a rate of up to $\sim 10 \mathrm{~cm} / \mathrm{y}$ (Hulme et al., 2010). Discharge at rates of meters per year was identified from push cores collected in 2003 by the remotely operated vehicle (ROV) Jason II within a $50 \mathrm{~m}$ range of the piston core with the greatest fluid upwelling rate.

Coring on the flank of Yinazao Seamount, as on those of the other two target mud volcanoes, was designed to recover some of the oldest serpentinite mudflow materials. We anticipated recovering matrix muds and rock clasts that would provide information re- garding the lithology of these early erupted materials. Serpentinized peridotite clasts and other lithologies might reveal different decollement pressure, temperature, and compositional conditions from those that would be expected in the earlier stages of the forearc evolution. It was also expected that interstitial waters would have interacted with seawater after lengthy exposure at the base of the seamount. Such interactions may affect microbial communities present in the subseafloor environment. Each of the five flank sites on these three seamounts is located on a multichannel seismic (MCS) line (Oakley, et al., 2007; Oakley, 2008) that intersected either a region of the flank that was undisturbed by mass-wasting or that crossed the distal edge of a mudflow of particular interest.

Fantangisña Seamount (informally known as Celestial Seamount) is located about $62 \mathrm{~km}$ from the trench (Figure F1). Based on MCS data, it lies about $14 \mathrm{~km}$ above the subducting Pacific plate (Table T1). This seamount lies on the northern edge of a prominent uplifted forearc block that trends northwest and is intersection by a northeast-trending lineament. The main feature of the summit is a slump on the northern flank. Several stages of slumps exist, based on nested headwalls with sharply defined features at 2000 and 1840 $\mathrm{m}$ water depth, for example.

No active seeps or chimneys were observed during the one ROV Jason II dive (J2-038) on Fantangisña Seamount in 2003. This dive started within the summit depression at the headwall of a low-relief $2000 \mathrm{~m}$ slump scar and traversed up the southeastern slope to the summit rim. The only indication of active serpentinite mud volcanism is based on one piston core from the center of the summit depression. This core recovered $40 \mathrm{~cm}$ of serpentinite material; however, at the base of the core, concentrations of $\mathrm{Mg}$ and alkalinity (49.6 and $0.89 \mathrm{mmol} / \mathrm{kg}$, respectively) in interstitial waters were lower than bottom seawater values $(53$ and $2.4 \mathrm{mmol} / \mathrm{kg}$, respectively). These data indicate a deep-sourced input close to the seafloor, consistent with slow, centimeters per year or less discharge of interstitial waters.

Asùt Tesoru Seamount (informally called Big Blue Seamount) is a serpentinite mud volcano that lies about $72 \mathrm{~km}$ from the trench axis with the subducting slab approximately $18 \mathrm{~km}$ below its summit (Oakley et al., 2007, 2008) (Figure F1; Table T1). Asùt Tesoru Seamount is the farthest from the trench of the three seamounts targeted for coring. It is also the largest one on the Mariana forearc, with a diameter of $\sim 50 \mathrm{~km}$ and over $2 \mathrm{~km}$ high. The major fault trend that controlled the growth of the edifice has a north-northeast trend and is crosscut by a fault trending north-northwest. Asùt Tesoru Seamount may have been active since the Eocene, based on analysis of two serpentine-bearing ( $~ 50 \%$ serpentine) sediment intervals immediately above Eocene basement recovered during Deep Sea Drilling Project (DSDP) Leg 60 at Site 459 (Despraires, 1982).

The summit region of Asùt Tesoru Seamount has a prominent mound at the intersection of the two fault trends. The summit mound is roughly circular and about $3 \mathrm{~km}$ in diameter and $200 \mathrm{~m}$ high. At its apex, it has three smaller circular mounds. One is centered at the middle of the $\sim 1.5 \mathrm{~km}$ plateau on top of the mound and is about $350 \mathrm{~m}$ in diameter and $40 \mathrm{~m}$ high. The two other mounds are about $200 \mathrm{~m}$ in diameter and $20 \mathrm{~m}$ high. The two smaller mounds lie side by side west of the larger mound and are both overlapped by it. An ROV transect of the larger mound was conducted in 2003 with the Jason II (J2-034 and J2-036) from west to east. The highest rate of fluid discharge occurred in the middle of the surveyed mound on the summit of the seamount.

South Chamorro Seamount is located about $78 \mathrm{~km}$ from the trench, with the subducting slab approximately $18 \mathrm{~km}$ below its 
summit; it was drilled during ODP Leg 195 (Figure F1; Table T1). This seamount is primarily composed of unconsolidated flows of serpentinite mud with clasts consisting dominantly of serpentinized peridotite but also includes greenschist and blueschist rock fragments from the subducted Pacific plate (Shipboard Scientific Party, 2002). The summit shows active fluid seepage of slab-derived fluids with megafaunal assemblages that include mussels, gastropods, worm tubes, and galatheid crabs (Fryer and Mottl, 1997). Subsurface microbes include archaea (Mottl et al., 2003; Curtis et al., 2013) and Bacteria (Takai et al., 2005). Even with evidence for fluid flow from a deep source (Hulme et al., 2010), temperatures measured in the uppermost $1 \mathrm{~m}$ at Site 1200 are between $2^{\circ}$ and $3^{\circ} \mathrm{C}$, which is just above the bottom water temperature of $1.7^{\circ} \mathrm{C}$.

During Leg 195, a borehole observatory (CORK) was deployed. This original-style CORK included a $202.8 \mathrm{~m}$ long casing with a screened section from about 148.8 to 202.3 meters below seafloor (mbsf). This screened section provides a conduit for formation fluids at depth to exchange with fluids within the borehole. When the borehole is open at the seafloor, fluids naturally discharge (Wheat et al., 2008). However, the lack of latches to maintain formation pressure and the small diameter imposed by the original-style CORK limit the usefulness of this installation. The plan for Expedition 366 was to remove the CORK body, leaving the hole open for a future ROV deployment of a CORK-Lite (Wheat et al., 2012).

\section{Objectives}

The four primary scientific goals outlined in the Expedition 366 Scientific Prospectus were to assess (1) mass transport processes in the Mariana forearc region, (2) spatial variability of slab-related fluids, (3) metamorphic and tectonic history and physical properties of the subduction zone, and (4) biological activity associated with deep-derived subduction zone material. To meet or address these goals, the specific objectives were to gain better insight into mass transport (fluids and solid materials) in the Mariana forearc region and its relationship to subduction zone tectonics and subseafloor biological processes. The sites chosen for drilling on the three target serpentinite mud volcanoes span different distances (and depth to slab) from the Mariana Trench. Results from Expedition 366 will therefore complement previous drilling completed during ODP Legs 125 and 195. In addition, the long-term goal of the expedition was to establish borehole observatory sites at the summits of the three seamounts targeted for coring.

To meet the specific objectives for coring during Expedition 366 , the operational plan was to (1) intersect mudflows of variable composition that mantled the flank of each edifice and, at the two that were known to be active, recover conduit muds from areas near active springs; (2) potentially date discrete mudflows paleontologically, should there be sediment layers between them; (3) determine variability in the composition of rock clasts in the mudflows; (4) investigate potential systematic variability in degree of serpentinization (possibly lower degrees at initiation of mud volcanism via conduit "throat clearing" or greater on the flanks where rock clasts may have reacted more fully with enclosing serpentinite muds and fluids); (5) examine transport conditions of muds and interstitial waters; (6) provide a measure for the scale of potential fluid discharge characteristics (e.g., diffuse versus channelized); (7) determine the composition of fluid from depth; and (8) collect samples for the study of microbial/viral community interactions at depth and if possible near the underlying forearc sediment surface under a range of conditions.
The primary objective for establishing borehole observatories was to deploy three screened and cased boreholes that bisect hydrologic zones (aquifers), one at each of the three summit sites on Yinazao, Fantangisña, and Asùt Tesoro Seamounts. These boreholes, each sealed with cement at their base, would then serve as the foundation for a return mission with an ROV to emplace CORKLites within the cased holes. CORK-Lites would enable downhole monitoring, experimental capabilities, and collection of pristine deep-source fluids within a gas-tight sampling system for dissolved gas analyses. Given the original-style CORK at South Chamorro Seamount, the objective was to remove the CORK body so the borehole could be used for a range of experiment types and instrument sizes.

\section{Coring results}

Three serpentinite mud volcanoes were cored during Expedition 366 (Yinazao, Fantangisña, and Asùt Tesoro Seamounts). Cored materials were recovered from each of the summit and flank sites using a variety of coring technologies designed for maximum recovery, penetrating hard materials, or achieving a desired depth (Table T2). Thus, combined with data from Legs 125 and 195, the new data from Expedition 366 provide a continuum from relatively $\operatorname{cool}\left(\sim 80^{\circ} \mathrm{C}\right)$ and shallow $(\sim 13 \mathrm{~km})$ conditions at depth within the subduction channel closer to the trench to hot $\left(\sim 350^{\circ} \mathrm{C}\right)$ and deep $(\sim 19 \mathrm{~km})$ conditions further from the trench. It is important to note that the depths to the slab given in Table T1 for Yinazao, Fantangisña, and Asùt Tesoro Seamounts are based on estimates from at least two MCS profiles across these edifices (Oakley et al., 2007, 2008; Oakley, 2008). However, for Conical and South Chamorro Seamounts there are no MCS data. As a consequence, a depth to slab estimate was determined for these edifices based on a number of assumptions. The estimate assumes (1) that the subducting Pacific plate is a smooth surface (i.e., has carried no subducted seamounts down, although the drilling results show it has), (2) that the trench itself is unperturbed by interaction with subducting seamounts and thus subtends a smooth curve that is an average of the thalweg position (Hulme et al., 2010) (bathymetry maps; e.g., Figure F1) (however, there are significant perturbations associated with impact from Pacific seamounts entering the trench), (3) that the plate subducts along the shortest perpendicular to a tangent of that average curve and that the distance of the seamount summit from the trench can be determined by measuring along that perpendicular, (4) that the angle of convergence between the Pacific plate and the trench lies along that perpendicular (though it does not), and (5) that paragenesis models using equilibrium assemblages of metamorphic minerals in subduction-channel-derived rocks recovered from coring and drilling on these two edifices do not fit a graphic model for depth to slab beneath the seamounts. The paragenesis models are described fully in Maekawa et al. (1993), Fryer et al. (2006), and Gharib (2006). Therefore, we used the depths of the three seamounts cored during this expedition, as estimated by MCS data, to fit a line defining a depth versus distance from the curve representing an average of the trench position and extrapolated that line to the distances of the summits of Conical and South Chamorro Seamounts as measured along the perpendicular to the tangent of the average trench-curve to establish an estimate for the depths to slab beneath those seamounts. Therefore, we caution the reader to bear in mind that depths to slab beneath the seamounts drilled during Legs 125 and 195 are certainly deeper than those drilled 
Table T2. Expedition 366 hole summary. Download table in CSV format.

\begin{tabular}{|c|c|c|c|c|c|c|c|c|c|c|c|}
\hline Hole & Latitude & Longitude & $\begin{array}{l}\text { Water } \\
\text { depth } \\
\text { (mbsl) }\end{array}$ & $\begin{array}{l}\text { Cores } \\
(N)\end{array}$ & $\begin{array}{l}\text { Interval } \\
\text { cored } \\
(\mathrm{m})\end{array}$ & $\begin{array}{l}\text { Core } \\
\text { recovered } \\
(\mathrm{m})\end{array}$ & $\begin{array}{c}\text { Recovery } \\
(\%)\end{array}$ & $\begin{array}{c}\text { Drilled } \\
\text { interval } \\
(\mathrm{m})\end{array}$ & $\begin{array}{c}\text { Total } \\
\text { penetration } \\
(\mathrm{m})\end{array}$ & $\begin{array}{l}\text { Time } \\
\text { on hole } \\
\text { (days) }\end{array}$ & Comments \\
\hline $1200 \mathrm{C}$ & $13^{\circ} 47.0724^{\prime} \mathrm{N}$ & $146^{\circ} 0.1717^{\prime} \mathrm{E}$ & 2932.16 & 0 & & & 0 & & & 1.2 & CORK recovery operation \\
\hline U1491A & $15^{\circ} 47.1175^{\prime} \mathrm{N}$ & $147^{\circ} 08.4909^{\prime} \mathrm{E}$ & 4493.68 & 1 & 1.3 & 1.32 & 101.54 & & 1.3 & 0.81 & \\
\hline U1491B & $15^{\circ} 47.1176^{\prime} \mathrm{N}$ & $147^{\circ} 08.4908^{\prime} \mathrm{E}$ & 4492.48 & 5 & 19.4 & 18.98 & 97.84 & & 19.4 & 0.68 & \\
\hline U1491C & $15^{\circ} 47.1940^{\prime} \mathrm{N}$ & $147^{\circ} 08.4119^{\prime} \mathrm{E}$ & 4518.88 & 9 & 34.2 & 23.08 & 67.49 & & 34.2 & 1.34 & \\
\hline U1492A & $15^{\circ} 42.6775^{\prime} \mathrm{N}$ & $147^{\circ} 10.6003^{\prime} \mathrm{E}$ & 3656.58 & 9 & 38.3 & 38.49 & 100.50 & & 38.3 & 1.72 & \\
\hline U1492B & $15^{\circ} 42.6216^{\prime} \mathrm{N}$ & $147^{\circ} 10.6011^{\prime} \mathrm{E}$ & 3669.10 & 13 & 51.4 & 52.03 & 101.23 & & 51.4 & 1.43 & \\
\hline U1492C & $15^{\circ} 42.5590^{\prime} \mathrm{N}$ & $147^{\circ} 10.6001^{\prime} \mathrm{E}$ & 3666.47 & 30 & 139.1 & 71.35 & 51.29 & & 139.1 & 3.36 & \\
\hline \multirow[t]{2}{*}{ U1492D } & $15^{\circ} 42.5694^{\prime} \mathrm{N}$ & $147^{\circ} 10.5991^{\prime} \mathrm{E}$ & 3666.44 & 0 & & & 0 & & & 9.79 & \\
\hline & & & & & & & & & & 1.19 & Reoccupation of Hole U1492D \\
\hline U1493A & $17^{\circ} 59.1668^{\prime} \mathrm{N}$ & $147^{\circ} 06.0057^{\prime} \mathrm{E}$ & 3358.92 & 1 & 0.1 & 0.09 & 90.00 & & 0.1 & 0.50 & \\
\hline U1493B & $17^{\circ} 59.1665^{\prime} \mathrm{N}$ & $147^{\circ} 06.0060^{\prime} \mathrm{E}$ & 3358.92 & 9 & 32.6 & 19.03 & 58.37 & & 32.6 & 1.44 & \\
\hline U1494A & $18^{\circ} 3.0896^{\prime} \mathrm{N}$ & $147^{\circ} 6.0003^{\prime} \mathrm{E}$ & 2199.80 & 10 & 39.0 & 27.99 & 71.77 & & 39.0 & 1.03 & \\
\hline U1495A & $18^{\circ} 05.6693^{\prime} \mathrm{N}$ & $147^{\circ} 06.0004^{\prime} \mathrm{E}$ & 1405.81 & 3 & 10.7 & 4.84 & 45.23 & & 10.7 & 0.62 & \\
\hline U1495B & $18^{\circ} 05.6788^{\prime} \mathrm{N}$ & $147^{\circ} 05.9901^{\prime} \mathrm{E}$ & 1401.89 & 4 & 10.8 & 10.18 & 94.26 & & 10.8 & 3.35 & \\
\hline U1496A & $18^{\circ} 6.5936^{\prime} \mathrm{N}$ & $147^{\circ} 6.0999^{\prime} \mathrm{E}$ & 1243.38 & 10 & 42.8 & 38.36 & 89.63 & 2 & 44.8 & 0.66 & \\
\hline U1496B & $18^{\circ} 6.6205^{\prime} \mathrm{N}$ & $147^{\circ} 6.0998^{\prime} \mathrm{E}$ & 1240.18 & 9 & 30.0 & 22.08 & 73.60 & 6 & 36.0 & 0.94 & \\
\hline \multirow[t]{2}{*}{ U1496C } & $18^{\circ} 06.6068^{\prime} \mathrm{N}$ & $147^{\circ} 06.1001^{\prime} \mathrm{E}$ & 1243.17 & 11 & 105.0 & 8.52 & 8.11 & & 105.0 & 3.78 & \\
\hline & & & & & & & & & & 0.85 & Reoccupation of Hole U1496C \\
\hline U1497A & $16^{\circ} 32.2536^{\prime} \mathrm{N}$ & $147^{\circ} 13.2642^{\prime} \mathrm{E}$ & 2019.24 & 9 & 34.2 & 22.47 & 65.70 & & 34.2 & 0.20 & \\
\hline U1497B & $16^{\circ} 32.2528^{\prime} \mathrm{N}$ & $147^{\circ} 13.2606^{\prime} \mathrm{E}$ & 2018.22 & 6 & 23.8 & 19.91 & 83.66 & & 23.8 & 0.56 & \\
\hline U1497C & $16^{\circ} 32.2504^{\prime} \mathrm{N}$ & $147^{\circ} 13.2500^{\prime} \mathrm{E}$ & 2018.30 & 0 & & & 0 & & & 0.42 & \\
\hline \multirow[t]{2}{*}{ U1497D } & $16^{\circ} 32.2548^{\prime} \mathrm{N}$ & $147^{\circ} 13.2621^{\prime} \mathrm{E}$ & 2018.80 & 0 & & & 0 & & & 8.00 & \\
\hline & & & & 0 & & & & & & 0.71 & Reoccupation of Hole U1497D \\
\hline & $16^{\circ} 27.0898^{\prime} \mathrm{N}$ & $147^{\circ} 09.8502^{\prime} \mathrm{E}$ & 3496.21 & 19 & 181.6 & 20.59 & 11.34 & & 181.6 & 1.85 & \\
\hline \multirow[t]{2}{*}{ U1498B } & $16^{\circ} 27.3716^{\prime} \mathrm{N}$ & $147^{\circ} 10.1166^{\prime} \mathrm{E}$ & 3284.70 & 27 & 260.0 & 82.82 & 31.85 & & 260.0 & 4.83 & \\
\hline & & & Totals: & 185 & 1054.3 & 482.13 & 45.73 & 8 & 1062.3 & 51.26 & \\
\hline
\end{tabular}

during Expedition 366 but may be subject to errors on the order of perhaps a few kilometers.

Materials recovered during drilling operations were analyzed using standard techniques commonly utilized during IODP expeditions. We present a summary of these data types and an initial interpretation organized by shipboard laboratory, providing an integrated model of subsurface processes based on data from each of the three cored sites. Each laboratory began the process of comparing and contrasting results from summit sites, which represent the most pristine materials in terms of transport from depth, and flank sites, where eruptive materials overlie previous deposits and have undergone alteration reactions made possible through diffusive exchange with overlying oxic bottom seawater. Ultimately, results from the various laboratories will be integrated to provide greater constraints for evaluating mass transport, temporal variability, metamorphic and tectonic history, and microbial mechanisms and activity.

\section{Lithostratigraphy, petrology, and structure}

Material recovered during Expedition 366 consists primarily of serpentinite mud (Zone 1 in Figure F2) containing lithic clasts derived from the underlying forearc crust (Zone 2 in Figure F2) and mantle and the subducting Pacific plate. A thin cover of pelagic sediment was found at many sites, whereas pelagic sediments and volcanic ash deposits were cored underlying serpentinite mudflows on the distal flanks of one of the three cored seamounts (Zone 3 in Figure F2). The conceptual model for serpentinite mud volcanism processes within forearc/subduction complex is best described with a cross-section perpendicular to the trench (depicted schematically in Figure F2). Here, we describe in more detail the results from each site cored during Expedition 366.
The bulk of the material recovered in the cores is serpentinite mudflow matrix (Zone 1 in Figure F2). The matrix ranges from pale green to dark blue-gray, except in the upper few meters of material recovered on the flanks of the seamount, where the serpentinite is typically oxidized to a yellow-orange color. The serpentinite mud consists largely of clay- to silt-sized serpentine grains plus accessory phases such as Fe oxide (magnetite and/or hematite), brucite, spinel, calcite, hydrogarnet, talc, tremolite, and chlorite. Secondary alteration minerals include sjogrenite group minerals, clays, aragonite, and gypsum. Authigenic aragonite, as single acicular needles or radiating clusters of acicular crystals, is common in the upper few tens of meters. Some serpentinite mud horizons appear to be reworked; these horizons may contain pelagic nannofossils, volcanic ash, and mineral fragments (e.g., clinopyroxene). Clast contents vary from $<1 \mathrm{vol} \%$ to more than $35 \mathrm{vol} \%$ lithic clasts, with a mode of around $5 \mathrm{vol} \%$ lithic clasts.

Ultramafic clasts are the dominant clast type (Zone 4) and are mainly serpentinized harzburgite $(<<5 \%$ clinopyroxene) with less common dunite and pyroxenite. The range in degree of serpentinization is broad, $30 \%-100 \%$ of the original material. Serpentinization is commonly pseudomorphic, and primary modes are inferred in most of the peridotites because the grain sizes for pyroxene (bastite) and spinel are largely unaffected. Primary textures were identified in most samples based on relict mineral phases or pyroxene-spinel relations. All dunites and most harzburgites (from Sites U1491, U1493-U1495, and U1497) are inferred to be porphyroclastic or coarse tabular primary textures with elongate, deformed olivine and enstatite, smaller strain-free neoblasts of olivine, as well as holly leaf-shaped interstitial spinel (e.g., Mercier and Nicolas, 1975; Lenoir et al., 2000). Olivine in some dunite samples occurs as scattered fragments with the same optical orientation that together form 
Figure F2. Idealized cross-section of the Mariana forearc setting, including the relative positioning of serpentinite mud volcanoes. Tectonic Zones 1-6 in the forearc subduction zone complex are keyed to core images in this figure and to some of the photomicrographs in Figure F3. Figure modified after Fryer et al. (1999).
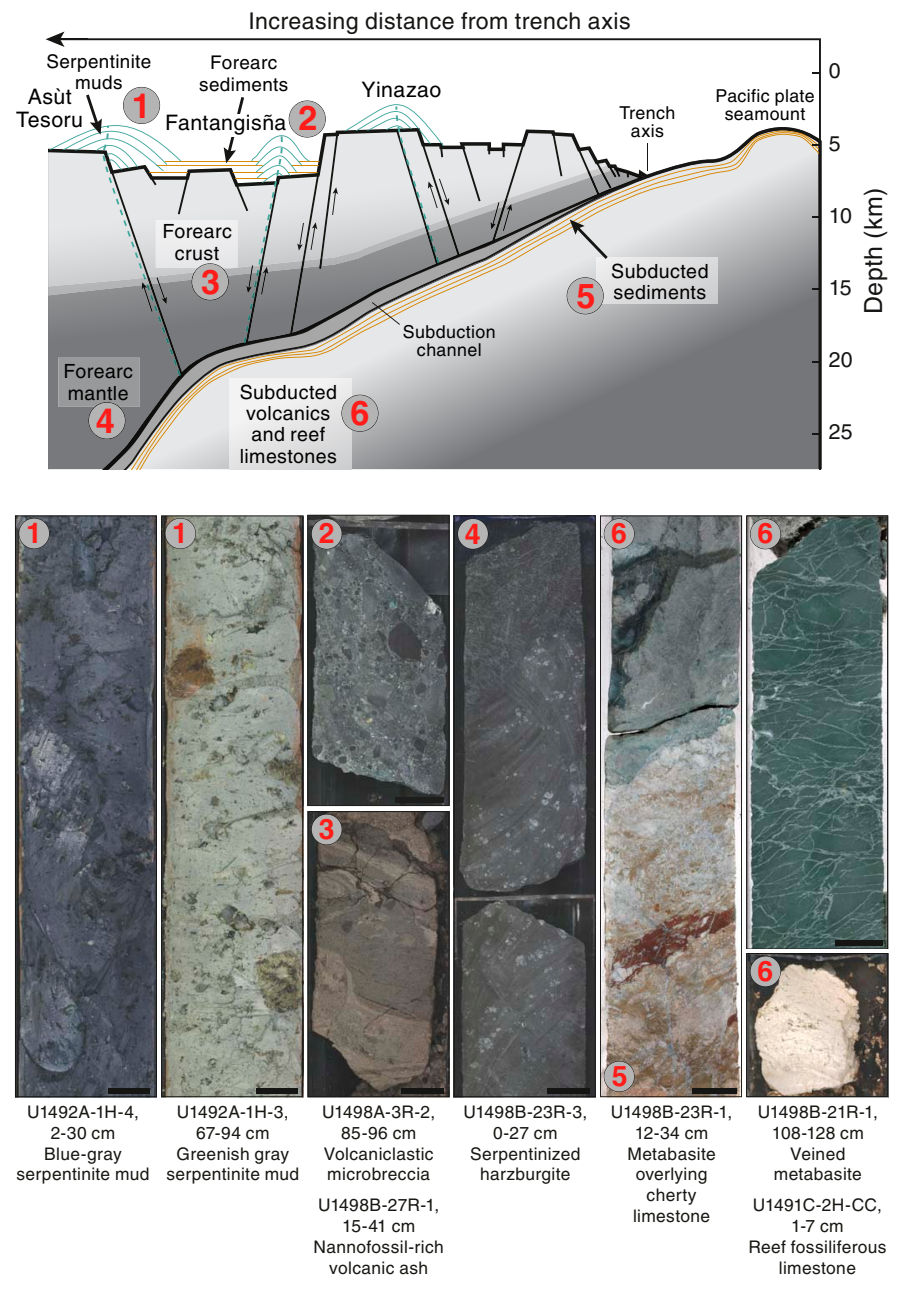

much larger (up to $1 \mathrm{~mm}$ ) deformed primary grains. These textures imply that serpentinite materials have undergone solid-state deformation in the lithosphere at relatively low temperatures.

By contrast, harzburgites from Sites U1492 and U1498 are characterized by protogranular textures, with vermicular spinel-pyroxene clusters inferred to represent decompression breakdown of garnet (Smith, 1977; Bhanot et al., 2016). The protogranular textures are overprinted by a subsequent texture formed in response to diffuse porous flow and reactive melt transport. Orthopyroxene has ragged lobate margins with sharp cusps that point into olivine grain boundaries (or former grain boundaries); some olivine grains have flat facets against orthopyroxene, signifying crystal growth faces in the presence of melt; and olivine also occurs as euhedral to anhedral inclusions within larger orthopyroxene grains. Resorbed orthopyroxene sometimes has an oikocrystic appearance, with scattered fragments with the same optical orientation. Textures resemble postcumulus textures in cumulate rocks. These textures are inferred to be melt infiltration textures formed by reactive diffuse porous flow of a low-silica melt. This melt is undersaturated in orthopyroxene, which melted incongruently to form a silica-rich melt and new olivine. Because the delicate apices of interstitial pyroxene
Figure F3. Representative samples keyed to zones and cores in Figure F2, Expedition 366. A. Discoasters (Dsc; Discoaster variabilis), coccoliths (C), and volcanic glass $(G)$ in volcanic ash deposits underlying Fantangisña Seamount (Zone 3). Microfossils establish an approximate age of $2.5 \mathrm{Ma}$ for the sediments under the mud volcano, thus establishing the maximum age of onlap of the mudflows from this part of the volcano. B. Elliptical pale green glass bleb with prismatic orthopyroxene (Opx) crystals in a microbreccia of presumed boninitic affinity (Zone 2; plane-polarized light [PPL]). C. Mildly serpentinized porphyroclastic clinopyroxene-bearing harzburgite $(40 \%$ serpentinization) (Zone 4; cross-polarized light [XPL]). Strained, granulated olivine (OI) porphyroclasts retain optical continuity. Orthopyroxene deformed with undulatory extinction. Clinopyroxene, commonly along orthopyroxene margins, may be granule exsolution. Spinel penetrates other mineral grain boundaries. D. Blue serpentine forming pseudomorphic mesh textures (Zones 1-4; PPL). Spl = spinel, bast = bastite. E. Ultracataclasite (Zone 5; PPL). Clasts of smeared chert and fossiliferous siliceous limestone within ultrafine-grained matrix. F. Euhedral-subhedral pink augite (Cpx) and plagioclase (PI) showing equigranular texture (Zone 6; PPL). Labeled, altered plagioclase shows relict albite twin.

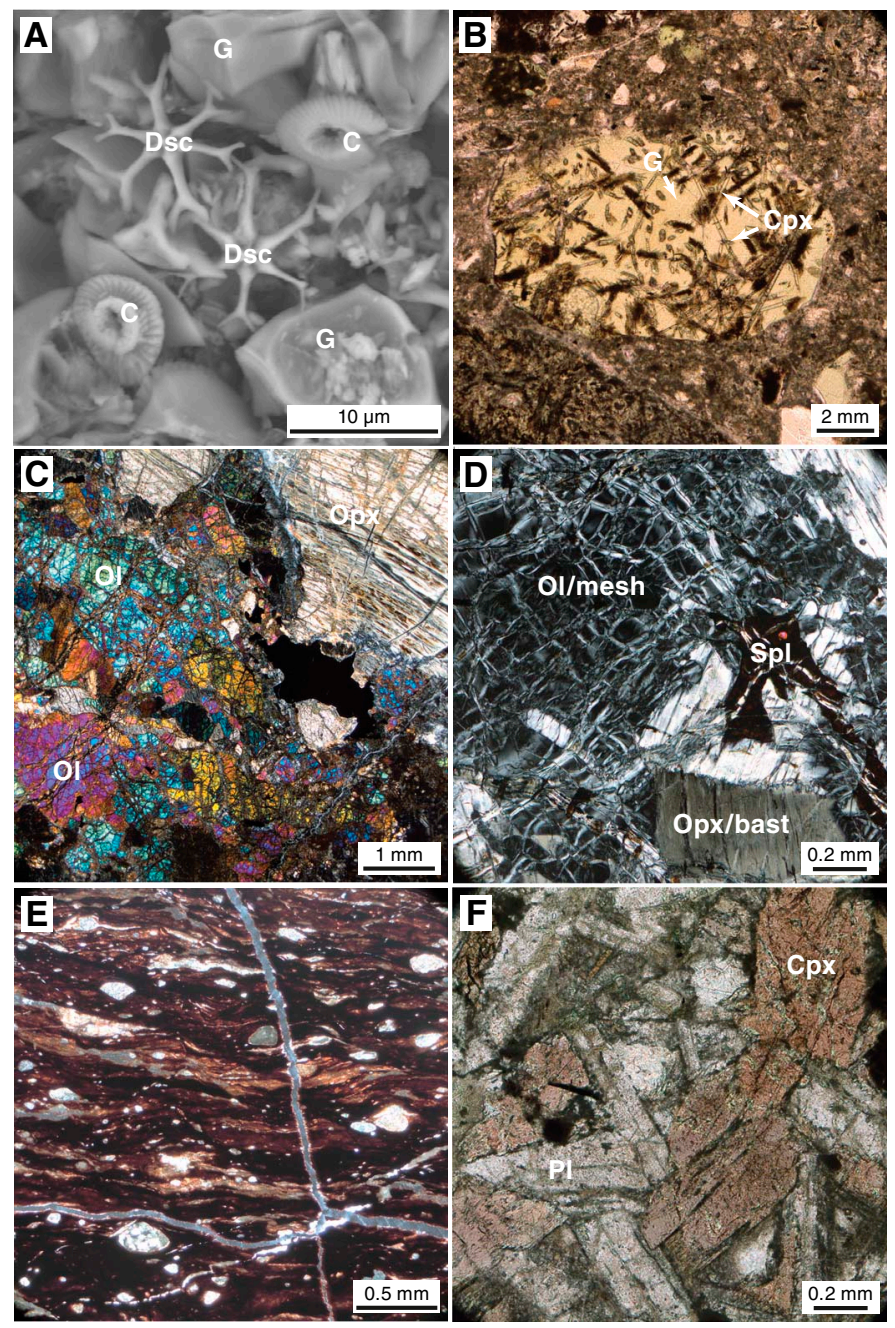

would likely be destroyed by solid-state flow in the lithosphere, we propose that this texture formed in the asthenosphere during melt production in response to subduction initiation.

No systematic changes of the serpentine textures were observed between the different sites (Zones 1-4 in Figures F2, F3). Serpentinized ultramafic rocks display mainly pseudomorphic mesh and bastite textures that replaced olivine and orthopyroxene, re- 
spectively. Such textures are likely composed of lizardite and chrysotile, but this assumption needs to be verified with postexpedition analyses. The mesh displays a pronounced blue color at Yinazao and Fantangisña Seamounts. Such coloration could be attributed to serpentine composition. Rare interpenetrating textures, which could correspond to the high pressure and temperature serpentine variety (antigorite), were mainly observed at Fantangisña and Asùt Tesoru Seamounts. Serpentinized ultramafic clasts are commonly crosscut by massive to fibrous veins of serpentine (chrysotile), crystallizing into isolated networks of fractures, some of which are conjugate and some of which display crack-seal-like textures within the vein center. Although the cored serpentinite mud volcanoes are located at different distances from the Mariana Trench, the absence of a clear variation of serpentine textures in the ultramafic clasts suggests that the serpentinization process occurs continuously from the slab/mantle interface to the surface and that each mud volcano includes ultramafic clasts that were serpentinized at a range of depths (temperature and pressure). Late stages of serpentinite alteration were observed within each mud volcano, mainly corresponding to breccia consisting of fragments of serpentine minerals, serpentinites, and clay minerals cemented by carbonate. The fragmentation obliterated previous serpentinite and mantle textures.

Crustal rocks derived from the underlying forearc crust and the subducting Pacific plate (Zones 3 and 6, respectively) were observed at several sites, but they form a major fraction of the recovered clasts at three sites: U1496 (Asùt Tesoru summit), U1497 (Fantangisña summit), and U1498 (Fantangisña flank). Low-grade metamorphosed sedimentary rocks and basalts were recovered from the summit site of Asùt Tesoru Seamount (Site U1496). The sedimentary clasts are fossiliferous cherty limestones. Some mafic volcanic clasts are dolerites and augite-phyric vitrophyres, and some contain pink titanaugite.

Volcanic clasts from Fantangisña Seamount include forearc basalts (Zone 3), boninite and volcanic glass (possibly boninitic), and greenstones and subgreenschist (prehnite-pumpellyite facies) metavolcanics (Zone 6). Metasediments from Sites U1497 and U1498 are characterized by recrystallization of calcareous and siliceous microfossils (Zone 5). The degree of recrystallization indicates low-grade metamorphic conditions. Metasedimentary and volcanic rocks are brecciated to varying degrees. Clasts from ultracataclastic shear zones with rounded clasts suggest deformation mechanisms along the plate boundary. Deformed sediment and volcanic rock clasts at these sites and at Site U1496 are consistent with a significant fraction of the material entrained by the Fantangisña and Asùt Tesoru Seamounts having been derived from the subducting Pacific plate (Zones 5 and 6), whereas clasts of boninite and volcanic glass were more likely from the oceanic crust of the Philippine Sea plate (Zone 3).

The seamounts overlie pelagic sediment rich in volcanic ash, which was sampled at Site U1498. This material is composed of volcanic ash, calcareous nannofossils (discoasters and coccoliths), foraminifers, radiolarians, and sponge spicules (Zone 2). The underlying volcanic ash establishes a maximum age for mud volcano activity or flank gravity sliding (Oakley et al., 2007). A similar pelagic sediment was recovered in the first cores from most flank sites; thus, paleontological analysis will help constrain the date of the most recent activity at each site.

\section{Site U1491}

Site U1491 is located on the flank of Yinazao Seamount near the base of a slight bathymetric valley. Mixed pelagic muds containing a variety of clastic materials were typically found at the tops of Holes U1491A (1.3 mbsf), U1491B (19.4 mbsf), and U1491C (34.2 mbsf) (Table T2). Beneath these pelagic sediments in Holes U1491B and U1491C, we recovered sequences of normally graded carbonatedominated breccia-conglomerate that are likely the result of comminution and drilling disturbance (via heave from the drill string) and serpentinite muds containing clasts of serpentinized ultramafic and occasionally carbonate (fossiliferous reef limestone). The nature of the lithologic units recovered in Holes U1491A-U1491C is consistent with the interpretation that these units represent serpentinite mudflows, the deepest of which tapped a source of carbonate clasts and serpentinized ultramafic rocks that are likely far less matrix supported than observed previously. The source of the carbonate materials is possibly an underlying subducted Cretaceous seamount.

\section{Site U1492}

Site U1492 is located on the summit of Yinazao Seamount along the extension of an inferred normal fault. Holes U1492A, U1492B, U1492C, and U1492D were drilled to $38.3,51.4,139.1$, and 228.8 mbsf, respectively; no materials were recovered from Hole U1492D (Table T2). Recovered materials from Holes U1492A and U1492C consist of an uppermost unit of blue-gray to light brown (oxidized) serpentinite pebbly mud with lithic clasts, Hole U1492B has a thin $(<0.4 \mathrm{~m}$ thick) upper unit of pelagic sediment overlying a lower unit of blue-gray serpentinite pebbly mud. The mudflow matrix contains $5 \%-10 \%$ lithic clasts of serpentinized ultramafic rock. The occurrence of pelagic mud in Hole U1492B at the summit rim of Yinazao Seamount is consistent with the observed sequence of predominantly serpentinite muds containing heavily serpentinized ultramafic clasts capped by a veneer of more oxidized, seawater-altered serpentinite muds and a spotty, thin pelagic sediment cover. Hole U1492C has an intermediate unit of green serpentinite mud. Ultramafic clasts in the lowermost portions of the boreholes display the most extreme degrees of serpentinization, with continuous transition toward plastically deforming components. Conversely, ultramafic clasts in the brown to light green uppermost intervals retain their hardness and frequently exhibit milder degrees of alteration.

\section{Sites U1493, U1494, and U1495}

Sites U1493, U1494, and U1495 were drilled on a line from south to north on the south flank of Asùt Tesoru Seamount (Table T2). The deepest site (U1493; 3359 meters below sea level [mbsl]) is the closest to the distal southern edge of the edifice. Hole U1493A was drilled to $0.1 \mathrm{mbsf}$, and Hole U1493B was drilled to $32.6 \mathrm{mbsf}$. Site U1494, with only one hole ( $39 \mathrm{mbsf}$ ) at $2200 \mathrm{mbsl}$, is close to the midflank of the edifice, and Site U1495, at $1400 \mathrm{mbsl}$, is located just south of the summit mound.

Serpentinite muds are covered by brownish pelagic mud at Sites U1493 and U1495 that contains volcanic ash, foraminifers, nannofossils, and minor diatoms and radiolarians. The thickness of the pelagic muds varies between sites, with approximately $80 \mathrm{~cm}$ in Hole U1493B, $0 \mathrm{~cm}$ in Hole U1494A (likely lost during mudline attempts), $25 \mathrm{~cm}$ in Hole U1495A, and $40 \mathrm{~cm}$ in Hole U1495B. Hole U1494A recovered an interval of mass flow between 6.9 and 8.78 mbsf that contains reworked serpentinite mud, volcanic ash, and brown muddy to silty fine sand with foraminifers that are assumed to derive from upslope sedimentary deposits. Holes U1495A (10.7 mbsf) and U1495B (10.8 mbsf) exposed a sequence of sandy silt with foraminifers and aragonite crystals overlying oxidized brownish and greenish gray serpentinite pebbly mud. The brownish gray 
serpentinite pebbly mud contains authigenic aragonite crystals and lithic clasts. The greenish gray serpentinite pebbly mud contains lithic clasts and occasional layers of matrix-supported breccia-conglomerate.

The three sites share a generally common stratigraphy that differs in detail with location. Uppermost recoveries consist of layers of either reddish oxidized sediments or mixed blue-gray and orange (oxidized) serpentinite pebbly mud. The pelagic sediments include microfossils and volcanic ash. The thickness of pelagic sediments generally decreases upslope. Beneath the most oxidized layer of serpentinite mud, mudflows tend to grade from pale green to dark blue with depth although they are intercalated with lighter green serpentinite muds in some depth intervals.

Small clasts of mafic igneous rocks were enclosed in the mudflows. They include metabasalts displaying green (chlorite and possibly epidote) and pale red (carbonate) layers. The compositions of the mafic rock clasts indicate that they are part of the subducted oceanic crust from the Pacific plate, altered by low-grade metamorphism and seafloor hydration processes.

\section{Site U1496}

Material from the summit of Asùt Tesoru Seamount (Holes U1496A [44.8 mbsf] and U1496B [36 mbsf]; Hole U1496C had no recovery) is characterized by a dominance of pale green serpentinite mud with a low proportion of lithic clasts compared with the seamount's flanks and other sites (Table T2). The pale green serpentinite mud is typically soupy or very soft due to high gas contents and often continued to out-gas days later. Dark blue serpentinite mud is uncommon, but when present it is characterized by higher clast counts. These characteristics are consistent with an active summit site that is currently producing high-pH water and abiotic hydrogen and methane.

Although less common than at other sites, hard rock clasts derived from the seamount summit mound provide important insights into the plumbing system of the mud volcano. Most common are ultramafic clasts, typically highly serpentinized harzburgites with less common dunite and orthopyroxenite. These materials likely derive from the underlying forearc mantle lithosphere.

We also recovered clasts of mafic metavolcanic and sedimentary rock. Sedimentary clasts include a fossiliferous, cherty limestone that may be pre-Eocene in age. Mafic metavolcanic clasts include dolerites with pink titanaugite and augite-phyric vitrophyres. The presence of titanaugite in these rocks indicate that their protoliths were alkali basalts. They are interpreted to be recycled material from subducted seamounts of the Pacific plate.

\section{Site U1497}

Four holes were drilled at Site U1497 on the summit of Fantangisña Seamount (Holes U1497A [34.2 mbsf] and U1497B [23.8 mbsf]; no recovery from Holes U1497C and U1497D) (Table T2). The occurrence of deformed sediments and volcanic rocks at this site suggests that a significant fraction of the material entrained by this mud volcano is derived from the subducting Pacific plate. In particular, titanaugite-bearing volcanic rocks imply mildly alkaline volcanic series in an ocean island seamount. In addition, the deformed sediments appeared to contain microfossils, such as radiolarians, that are representative of older (Mesozoic?) sediment from the Pacific plate. The presence of ultracataclasite, which requires severe brittle deformation, is unlikely to have occurred in sediments that were lying on top of the upper plate. Deformation of the Pacific plate as it bends on approach to the Mariana Trench and moves within the subduction channel could easily entail sufficient strain to produce these textures.

Mantle-derived harzburgites from Site U1497 are fully serpentinized but retain evidence of primary textures. They are characterized by pseudomorphs of orthopyroxene porphyroclasts that are highly elongated (in one case $4 \mathrm{~mm} \times 0.4 \mathrm{~mm}$ ), with kink folds and undulatory extinction. Spinel occurs in association with pyroxene and with subhedral to holly leaf shapes, $1-2 \mathrm{~mm}$ in size. We interpret these observations to indicate altered porphyroclastic textures, consistent with deformation at relatively low temperatures and moderate to high rates of strain. The (meta-) sediments are characterized by recrystallization of calcareous and siliceous microfossils. The degree of recrystallization indicates low-grade metamorphic conditions. Both the metasedimentary and metavolcanic rocks are brecciated to varying degrees. Brecciation resulted in the development of fine-grained cataclasite to ultracataclasite domains. The very fine grained sediments (shales and sandstones) were partly transformed into ultracataclastic shear zones with rounded clasts. The very small grain size $(<2 \mu \mathrm{m})$ within these shear zones indicates that the general deformation mechanism was ductile flow. Shear might have been localized along these shear zones. In general, brecciation (fracture) implies cataclastic deformation mechanisms (fracture and friction) at low-grade, moderate to high strain rates.

\section{Site U1498}

Site U1498 is located on the flank of Fantangisña Seamount. Hole U1498A (181.6 mbsf) is on the extreme southwestern flank, very close to the distal edge of the edifice and immediately downslope from a distinct break in slope of the lower flank (at 3507.5 mbsl) (Table T2). Hole U1498B (260 mbsf; $3296.0 \mathrm{mbsl}$ ) is $700 \mathrm{~m}$ upslope northeast of Hole U1498A. Lithologies recovered at Site U1498A, with increasing depth in hole, include yellowish oxidized pelagic muds with pelagic microfossils; intercalated blue, green, and yellow-orange serpentinite mudflow matrix silts and sands; partially serpentinized ultramafic rocks (harzburgite and dunite); mafic metavolcanic rocks and boninites; and, at the bottom of the hole, nannofossil- and volcanic ash-rich sedimentary rocks (siltstones and fine sandstones). In addition, Hole U1498B returned a large ( 2 m) compound clast of ultramafic rock, mafic metavolcanic rock, metalimestone, and metachert, likely originally within a serpentinite mud matrix, which was not recovered because the use of rotary coring likely washed out any existing matrix. All but the ultramafic rock is suspected to be part of a Cretaceous seamount.

The recovered clasts from Hole U1498B provide a particularly illuminating sequence of materials that deserves more detailed description. With increasing depth, the recovery includes (1) partially altered (to clay) serpentinized ultramafic rock clasts (stones and boulders), (2) serpentinite pebbly mud with pebbles of serpentinized ultramafics, (3) boulders of serpentinized ultramafics with numerous fractures filled with chrysotile, and (4) boulders of metabasite and cherty limestone and clasts of boninite and volcanic glass. These clasts and boulders were likely embedded within serpentinite pebbly mud (observed adhering to some of them), much of which was probably washed out during rotary coring. The mudflow matrix is well preserved in Sections 366-U1498B-7R-1 through $21 \mathrm{R}-1,0-30 \mathrm{~cm}$, with intermittent boulders, although it does show drilling disturbance (flow-in). The most surprising recovery occurs in Core 21R. In Section 21R-1, $116 \mathrm{~cm}$, there is a preserved and presumed inverted primary contact between a boulder of metabasite (35-116 cm; interpreted to be "igneous basement") and a boulder of cherty limestone (116-132 cm and continuing into Section 22R-1, 
0-81 cm; interpreted to be "sedimentary cover," i.e., originally overlying the metabasite). The deformed cherty limestone appears to contain microfossils such as radiolarians that are common in older sediments from the Pacific plate. The texture and mineralogical composition of the metabasite (greenstone with chlorite and amphibole) and cherty limestone indicate low- to possibly mediumgrade metamorphic overprint of these lithologies. These two boulders are clearly distinct from the volcanic rocks (boninites and forearc basalts) of the overriding Mariana forearc crust. The metabasite and limestones are consistent with a lower plate origin, and their paragenesis and position within the serpentinite mudflow matrix material suggests a dynamic overturning during exhumation. Furthermore, preserved cataclastic faults and extensional structures within these boulders (high-angle normal faults and extensional veins) may be related to (1) shearing within the subduction channel and bending of the lower plate during subduction, (2) accretion and vertical tectonism of intact seamount/guyot masses into the forearc region, or (3) faulting during the early stages of exhumation. The presence of ultracataclasite in the cherty limestone boulder requires severe brittle deformation that would not likely occur in sediment from the overriding forearc crust. At the base of Section 22R-CC, $81-93 \mathrm{~cm}$, is a serpentinite mudflow matrix that continues to Section 23R-1, $12 \mathrm{~cm}$. A boulder of greenstone with numerous fractures infilled with white secondary precipitate was observed in Section 23R-1, 12-81 cm. At Section 24R-1, $9 \mathrm{~cm}$, we recovered a contact between serpentinite mud matrix containing serpentinized ultramafic rock and dark-gray, pelagic, vitric silt and volcanic ash that contains microfossils. We thus achieved our goal of penetrating into the sediment that predates serpentinite flows at this site. Beginning at Section 27R-1, $13 \mathrm{~cm}$, we recovered intercalated pelagic, light tan to medium brown layers of pelagic, silty clay and volcanic ash that persisted to the end of the hole.

\section{Sediment and rock chemistry}

A selection of representative serpentinite mudflow matrix, various igneous and sedimentary rocks, serpentinite mud, and sediments recovered during Expedition 366 were analyzed with the new portable X-ray fluorescence spectrometer (pXRF). On the basis of these and visual results, a subset of materials was powdered for a suite of ship- and shore-based analyses (Table T3). In addition, a thin section was located next to each of the powered rock samples. At sea, powered samples were analyzed using standard inductively coupled plasma-atomic emission spectroscopy (ICP-AES) techniques to measure concentrations of $\mathrm{Al}_{2} \mathrm{O}_{3}, \mathrm{CaO}, \mathrm{Fe}_{2} \mathrm{O}_{3}, \mathrm{MgO}$, $\mathrm{MnO}, \mathrm{Na}_{2} \mathrm{O}, \mathrm{SiO}_{2}, \mathrm{TiO}_{2}, \mathrm{Ni}, \mathrm{Cr}, \mathrm{Sr}, \mathrm{Ba}, \mathrm{Sc}, \mathrm{V}$, and $\mathrm{Zr}$ and the pXRF was used to determine concentrations of $\mathrm{Al}_{2} \mathrm{O}_{3}, \mathrm{Fe}_{2} \mathrm{O}_{3}, \mathrm{CaO}, \mathrm{Cr}, \mathrm{Cu}$, $\mathrm{MgO}, \mathrm{Mn}, \mathrm{Ni}, \mathrm{Cr}, \mathrm{Zn}, \mathrm{SiO}_{2}$, and $\mathrm{Sr}$ (Table T4).

Recovered serpentinites are largely uniform in composition, with serpentinized ultramafic rocks and serpentinite muds spanning a limited range in $\mathrm{SiO}_{2}, \mathrm{MgO}$, and $\mathrm{Fe}_{2} \mathrm{O}_{3}$ compositions (Figure F4). No significant site-to-site or seamount-to-seamount variability was evident in these major elements or in the variations in $\mathrm{Al}_{2} \mathrm{O}_{3}$, which range from 0.1 to $1.7 \mathrm{wt} \%$ with a mean value of $\approx 0.6 \mathrm{wt} \%$ (Ta-

Table T3. pXRF results for rock surfaces in Expedition 366 cores. Download table in CSV format.

Table T4. ICP-AES and pXRF shipboard data for serpentinized ultramafic clasts, serpentinite muds, and entrained metamorphosed mafic rocks chosen for full chemical analysis during Expedition 366. Download table in CSV format. ble T3). This range is similar to the ranges reported by Savov et al. (2005a, 2005b, 2007) for serpentinized ultramafic clasts from Conical Seamount and for mudflow matrix and clasts from South Chamorro Seamount.

Fluid-immobile minor and trace elements $\mathrm{Ni}, \mathrm{Cr}, \mathrm{Zn}, \mathrm{V}$, and Sc show no clear distinctions from site to site or seamount to seamount in the serpentinized ultramafic rocks (Figure F5). V, Sc, Mn, and $\mathrm{Zn}$ show regular patterns of variation; these elements appear not to be redistributed by fluid-rock exchanges associated with serpentinization. $\mathrm{TiO}_{2}$ variations in serpentinites differ from those of the other immobile elements in that there may be site-related variability, with higher values evident for Site U1496 samples. However, Ti concentrations are close to the limits of detection using the shipboard ICP-AES, with only a fraction of our samples yielding detectable readings. It is equally possible that this small number of higher values were analytical artifacts.

Major and trace elements that are sensitive to redistribution by fluid-rock exchange processes with ultramafic rocks show more variable patterns (Table T3). $\mathrm{CaO}$ concentrations show considerable variability, ranging from $<0.01$ to $>10 \mathrm{wt} \%$ across a limited range in $\mathrm{MgO}$ values (Figure F6). A few samples analyzed from all three seamounts include rocks with both $\mathrm{CaO} \geq 10 \mathrm{wt} \%$ and high $\mathrm{MgO}$, suggestive of ultramafic cumulate bulk compositions for some of the serpentinized ultramafic rocks. A plot of $\mathrm{Na}_{2} \mathrm{O}$ versus $\mathrm{MgO}$ (Figure F6) shows an evident distinction between the serpentinized ultramafic clasts, which have $\mathrm{Na}_{2} \mathrm{O}$ values of $<0.4$ wt\%, and the serpentinite muds, which range as high as $2.0 \mathrm{wt} \% \mathrm{Na}_{2} \mathrm{O}$. Seamount-to-seamount variations are evident; serpentinite muds from the Asùt Tesoru summit site (U1496) have higher $\mathrm{Na}_{2} \mathrm{O}$ concentrations than those from the summits of Yinazao Seamount (Site U1492) or Fantangisña Seamount (Site U1497). Interstitial waters at the Asùt Tesoru summit extend to markedly higher abundances of $\mathrm{Na}$ than do those from the summits of Fantangisña or Yinazao Seamounts. Thus, the high $\mathrm{Na}_{2} \mathrm{O}$ in Asùt Tesoru muds may reflect equilibration with these $\mathrm{Na}$-enriched interstitial waters.

$\mathrm{Sr}$ concentrations in serpentinites are highly variable, ranging from $<5$ to $>6000 \mathrm{ppm}$ (Table T4). As with $\mathrm{Na}_{2} \mathrm{O}$, the serpentinized ultramafic clasts are lower in $\mathrm{Sr}$ abundance $(\leq 100 \mathrm{ppm})$, relative to the serpentinite muds $(100-6000+\mathrm{ppm}$; mean $\approx 600 \mathrm{ppm})$. In addition, there are clear seamount-to-seamount differences in the serpentinite composition of the muds, likely related to equilibrium with their associated interstitial waters. Yinazao Seamount muds (Site U1492; interstitial waters $>700 \mu \mathrm{M}$ ) are markedly higher in $\mathrm{Sr}$ than those from Asùt Tesoru Seamount (Site U1496; interstitial waters $\leq 10 \mu \mathrm{M}$ ). The highest $\mathrm{Sr}$ and $\mathrm{Ca}$ in serpentinite mud samples were found in near-surface cores and relate to the presence of authigenic aragonite and/or gypsum.

A small number of metamorphosed mafic volcanic and crustal rocks (sedimentary breccias, metamorphosed basalts, and boninites) were recovered, primarily from the summits of Asùt Tesoru Seamount (Site U1496) and Fantangisña Seamount (Sites U1497 and U1498) (Tables T3, T4). The metabasalts show elevated concentrations of $\mathrm{TiO}_{2}(1.6 \%-3.3 \%)$ and $\mathrm{K}_{2} \mathrm{O}(2.7 \%-6.7 \%)$ and range from 16 to $18.6 \mathrm{wt} \%$ in $\mathrm{Al}_{2} \mathrm{O}_{3}$, with highly variable $\mathrm{MgO}(2.5 \%-$ $11.3 \%)$ and $\mathrm{Na}_{2} \mathrm{O}(0.8 \%-3.5 \%)$ (Figure F7). Analyzed metabasite samples have Ni concentrations of $\sim 55 \mathrm{ppm}$, high V and Sc concentrations (up to 280 and 28 ppm, respectively) (Figure F5), Sr concentrations between 54 and $236 \mathrm{ppm}$ (Figure F6), Ba concentrations up to $88 \mathrm{ppm}$, and $\mathrm{Zr}$ concentrations between $\sim 240$ and $470 \mathrm{ppm}$. There is evidence for within-clast heterogeneity; samples from each of the two core sections characterized by mafic clasts (Sections 366- 
Figure F4. Major element variation of serpentinite muds and clasts, Expedition 366. Mafics = entrained metamorphosed mafic clasts. Molar MgO vs. FeO diagram after Hanson and Langmuir (1978), showing Expedition 366 ultramafic clasts and mafic clasts. Most Expedition 366 clasts fall in the residual mantle field, whereas mafic clasts are consistent with lavas formed from basaltic melts via varying degrees of fractional crystallization. Green fields reflect range of values from serpentinized ultramafic rocks collected on Conical and South Chamorro Seamounts and analyzed by Savov et al. (2007).
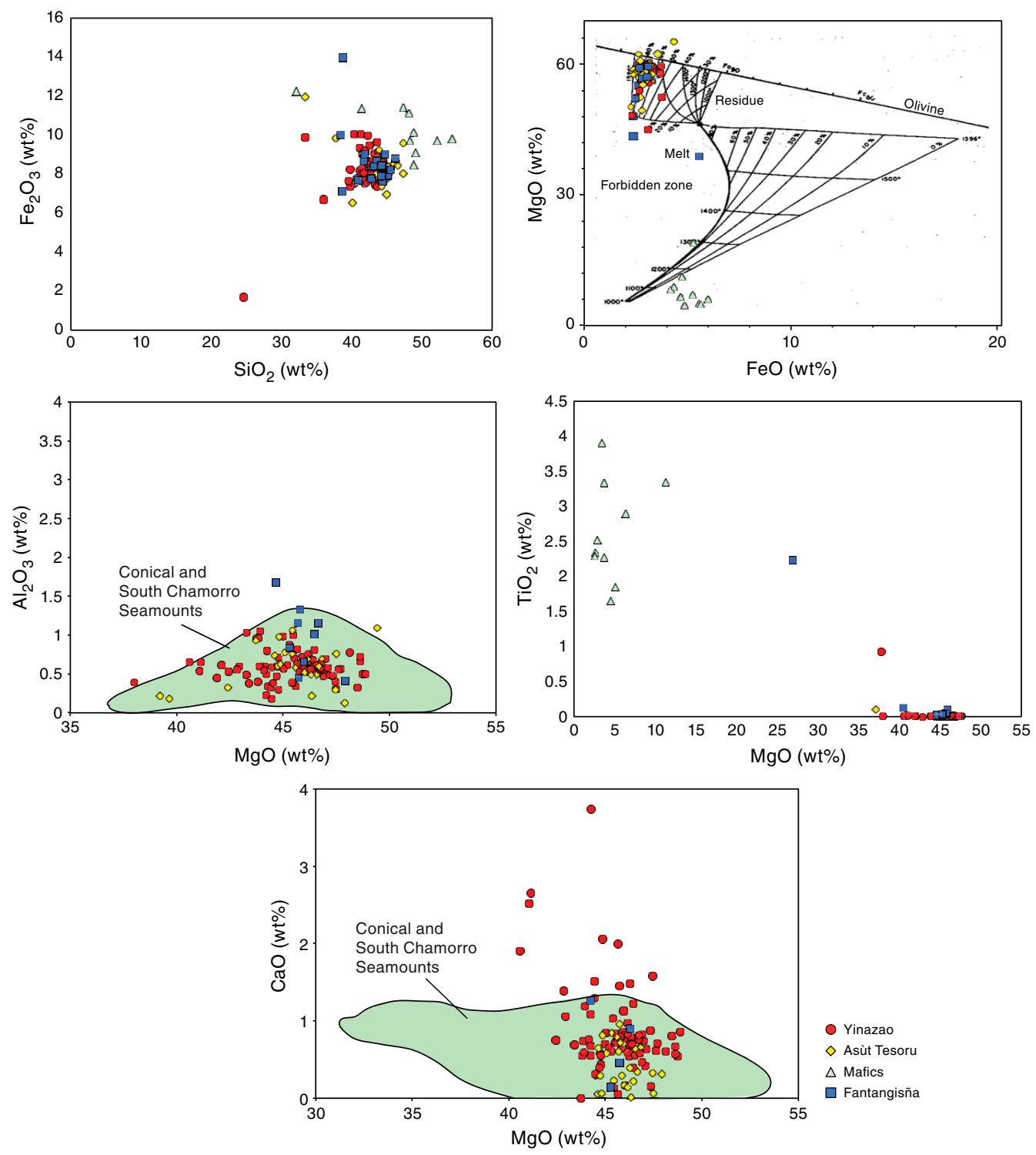

U1496B-8X-CC and 10F-2) show considerable variability in a number of immobile and mobile elements. Plotted on the Shervais (1982) V-Ti tectonic provenance diagram, these rocks are similar to those from the intraplate/alkali basalt field (Figure F5).

The metamorphosed mafic rocks resemble a subset of (1) samples recovered from dredges along a wall of a forearc graben north of the sites drilled during Expedition 366 (Johnson and Fryer, 1990) and (2) trachybasalts recovered from the western Pacific immediately outboard of the Mariana Trench (http://www.iedadata.org). These mafic rocks do not resemble the forearc tholeiite and boninite lavas that were known to comprise the volcanic crust of the outer Mariana forearc (e.g., Reagan et al., 2010). Thus, the most likely origin for these rocks is the downgoing Pacific plate, where seamounts that expose alkalic lavas are currently subducting.

\section{Interstitial water geochemistry}

Studies of interstitial water geochemistry from summit sites cored during Expedition 366 focused on collecting end-member compositional information, thus improving our overall understanding of the deep-sourced processes. In contrast, studies of interstitial waters from the flanks of the three cored seamounts focused on elucidating compositional changes of interstitial waters with time in the context of water-rock reactions, diffusive exchange with seawater, microbial activity, and processes associated with pelagic sediments that underlie serpentinite mud volcanoes in the Mariana forearc.

Analyses of dissolved gases $\mathrm{H}_{2}, \mathrm{CH}_{4}$, and $\mathrm{C}_{2} \mathrm{H}_{6}$ provide important insights into the physical and chemical conditions of the deep source. High concentrations of dissolved $\mathrm{H}_{2}, \mathrm{CH}_{4}$, and $\mathrm{C}_{2} \mathrm{H}_{6}$ were 
Figure F5. Immobile trace element variations in serpentinite muds and clasts, Expedition $366 . \mathrm{V}$ vs. Ti/1000 discriminator diagram for mafic and ultramafic samples (Shervais, 1982).
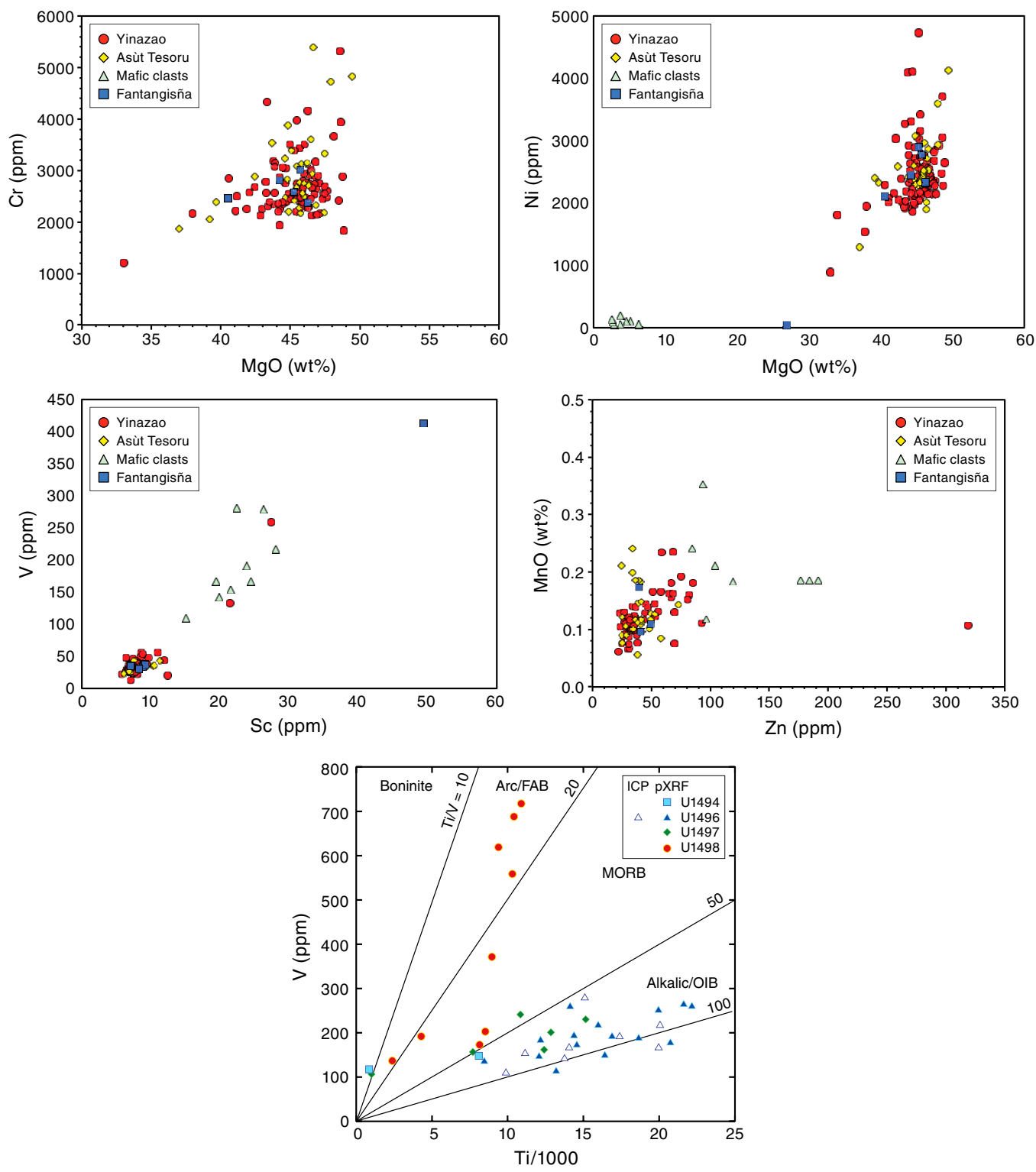

measured in samples from the summit of Asùt Tesoru Seamount, and comparatively low but significant levels were detected at Yinazao Seamount summit and flank sites. Variability in gas compositions among the three seamounts indicate differences in serpentinization and fluid migration processes. Dissolved $\mathrm{H}_{2}$ and $\mathrm{CH}_{4}$ (Figure F8A) show two groupings broadly consistent with thermodynamic estimates of serpentinization-driven $\mathrm{H}_{2}$ production (McCollom and Bach, 2009) and subsequent abiotic (Fischer-Tropsch Type) $\mathrm{CH}_{4}$ production.

Plots of methane versus ethane data from Asùt Tesoru, Conical, and South Chamorro Seamounts reveal linear trends (Figure F8B). Data from Asùt Tesoru Seamount are consistent with trends from South Chamorro and Conical Seamounts. These trends may reflect different methane consumption rates and/or methane production rates of subseafloor microbial communities, likely associated with habitability, abundance, and function. Both trends converge at a po- tential end-member composition $\left(\mathrm{CH}_{4}=60-100 \mathrm{mM}, \mathrm{C}_{2} \mathrm{H}_{6}=600-\right.$ $1000 \mu \mathrm{M}$, and $\mathrm{C}_{1} / \mathrm{C}_{2}$ ratio $\left.=100-150\right)$ that may represent the hydrocarbon values predominantly produced by abiotic (Fisher-Tropsch Type) synthesis processes at depth.

The chemical composition of deep-sourced interstitial waters was assessed along the continuum from shallow to deep source and from closest to farthest from the trench (Yinazao, Fantangisña, Asùt Tesoru, South Chamorro, and Conical Seamounts) (Table T1; Figure F9). Fluids from the summits of Yinazao and, to a lesser extent, Fantangisña Seamounts show elevated $\mathrm{Ca}$ and $\mathrm{Sr}$ and low to extremely low $\mathrm{K}, \mathrm{Na}, \mathrm{Cl}, \mathrm{SO}_{4}, \mathrm{~B}$, and $\mathrm{Na} / \mathrm{Cl}$ concentrations relative to bottom seawater. In contrast, fluids that upwelled at the summit of Asùt Tesoru seamount are similar in composition to those from South Chamorro and Conical Seamounts, with extremely high $\mathrm{pH}$ values (up to 12.4), $\mathrm{Ca}$ and $\mathrm{Sr}$ depletions, and marked enrichments in carbonate alkalinity, dissolved inorganic carbon (DIC), dissolved 
Figure F6. Variations of fluid-sensitive elements in serpentinite muds and clasts, Expedition 366.
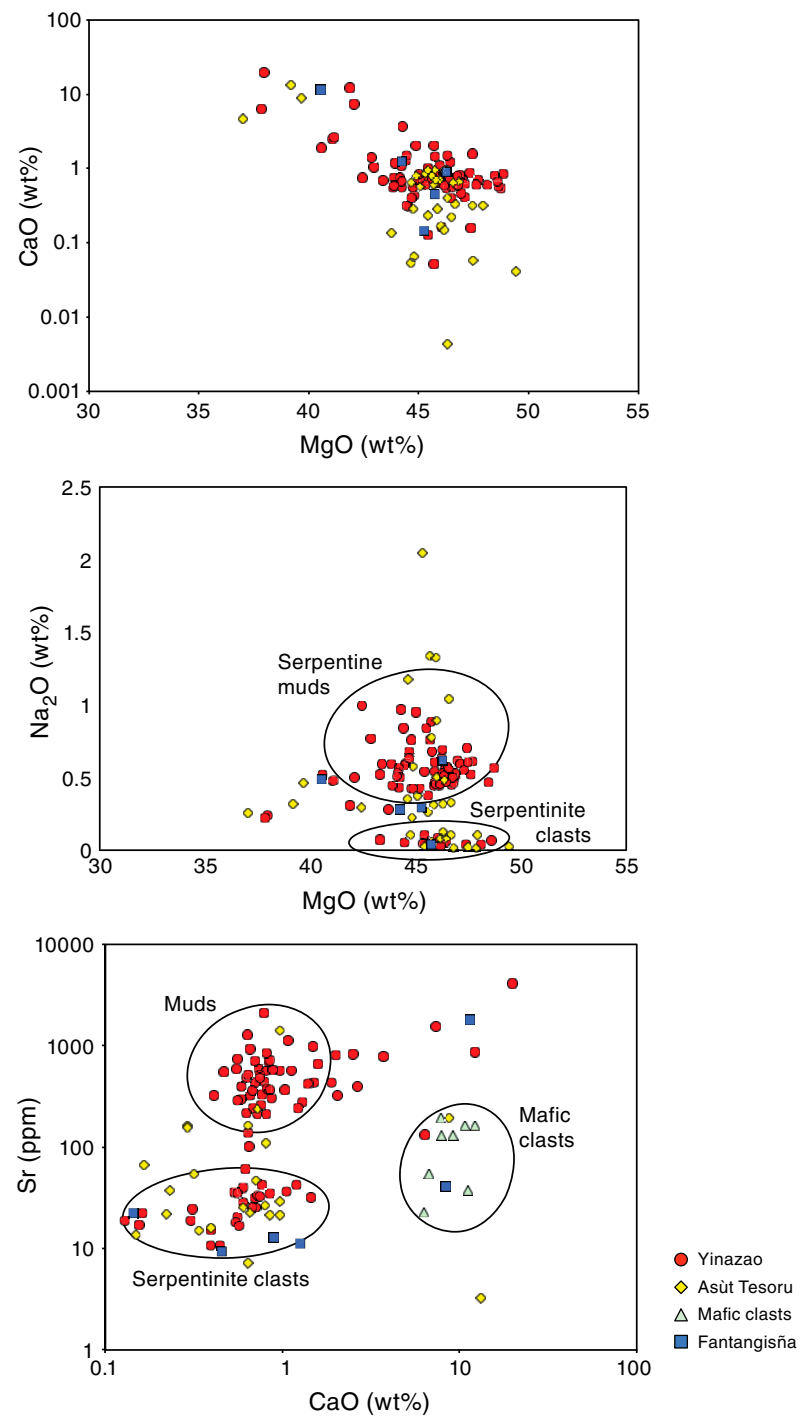

organic carbon (DOC), $\mathrm{NH}_{4}, \mathrm{Na}, \mathrm{K}, \mathrm{Na} / \mathrm{Cl}$, and $\mathrm{B}$. Na concentrations are higher at Asùt Tesoru than any of these five seamounts (Figure F9; see discussion below).

We mapped changes in the chemical composition of interstitial waters across the Mariana forearc in relation to subduction-related prograde diagenetic and metamorphic reactions that may trigger fluid and elemental releases (Figures F10, F11). Processes that occurred early (shallow) within the subduction system (i.e., Yinazao and Fantangisña Seamounts) were likely dominated by diagenesis and opal dehydration, whereas later processes (deeper) (i.e., Asùt Tesoru Seamount) included decarbonation and clay mineral decomposition (Fryer, Pearce, Stokking, et al., 1990; Haggerty, 1991; Haggerty and Chaudhuri, 1992; Haggerty and Fisher, 1992; Mottl, 1992; Mottl and Alt, 1992; Fryer et al., 1999; Mottl et al., 2003, 2004; Hulme et al., 2010; Wheat et al., 2008, 2010). Higher DIC at greater depths-to-slab is likely linked to carbonate decomposition within the slab. DIC reacting with $\mathrm{H}_{2}$ from serpentinization could produce $\mathrm{CH}_{4}$, light alkanes, or short-chained organic molecules (e.g., acetate and formate). $\mathrm{Ca}$ and $\mathrm{Sr}$ were sequestered from the fluids by car-
Figure F7. Elemental variations in metamorphosed mafic rocks compared to serpentinites, Expedition 366.
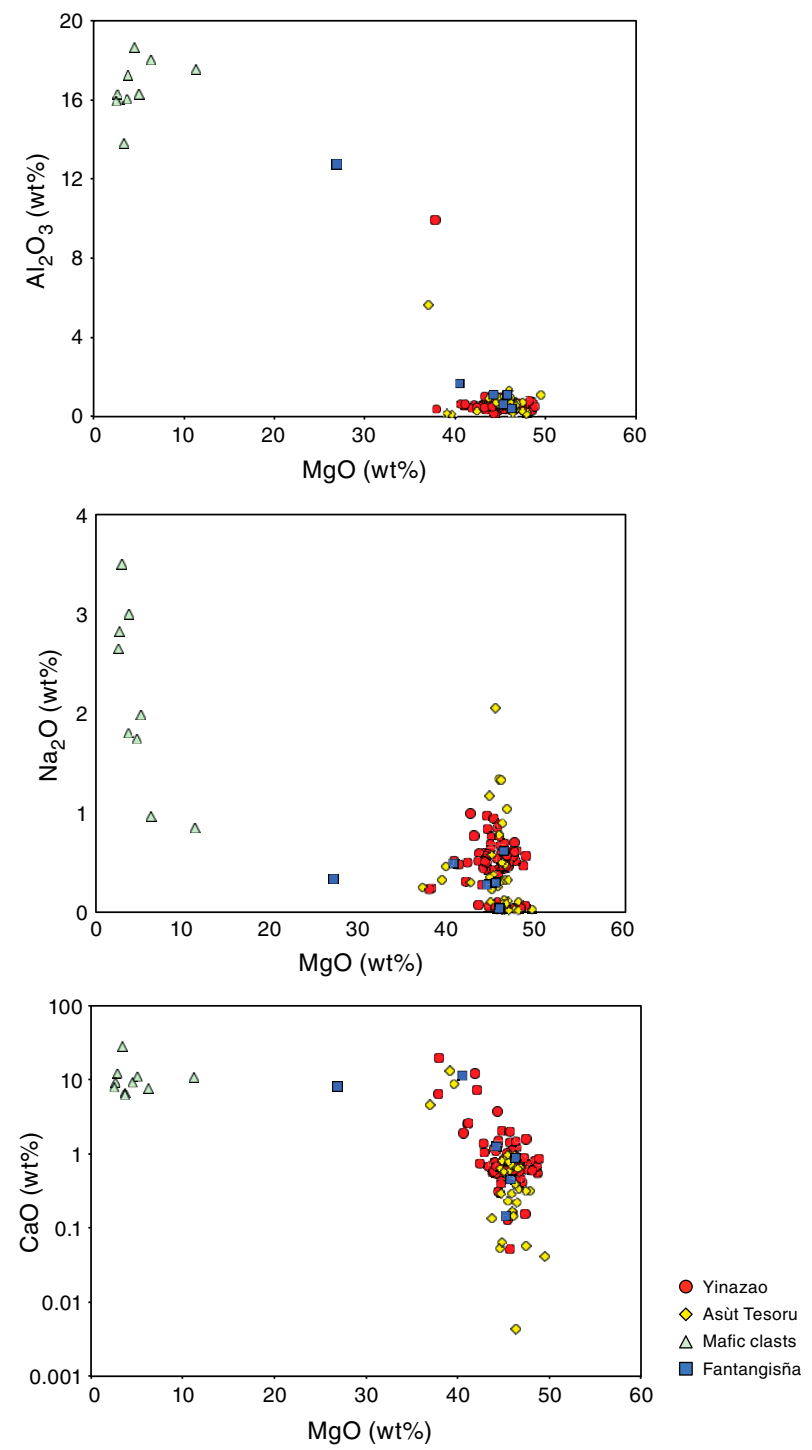

bonate precipitation (the lack of calcite in core samples from Asùt Tesoru Seamount suggests this reaction occurred slightly closer to the trench, which would exhaust $\mathrm{Ca}$ with continued $\mathrm{CO}_{3}{ }^{2-}$ production). Although Asùt Tesoru Seamount's interstitial waters are broadly similar to those studied at South Chamorro and Conical Seamounts, they are nonetheless distinct, with much higher $\mathrm{Na}$ and $\mathrm{Cl}$ concentrations and 3-4 times lower B contents. These differences likely reflect the lowest pressure-temperature (P-T) prograde metamorphic mineralogical reactions, impacting slab sediments and saponites that result in fluid release (Figure F11).

This slab signal is overprinted by low-temperature peridotiteseawater reactions and microbial interaction with fluids, particularly near the seafloor (Mottl et al., 2003; Takai et al., 2005; Curtis et al., 2013) and on the flanks of the seamounts. Initial interstitial water results from five flank sites cored during Expedition 366 indicate that the fluids are mixtures of slab-derived fluids that have undergone various degrees of alteration with serpentinite materials in the mud flows and exchange with overlying seawater. 
Figure F8. Gas compositions, Expedition 366. A. $\mathrm{H}_{2}$ vs. $\mathrm{CH}_{4}$, Yinazao and Asùt Tesoru Seamounts, Expedition 366. B. $\mathrm{CH}_{4}$ vs. $\mathrm{C}_{2} \mathrm{H}_{6}$ diagram for Asùt Tesoru, Conical and South Chamorro Seamounts. Data for Conical and South Chamorro Seamounts from Shipboard Scientific Party (1990, 2002; respectively). Star $=$ potential end-member composition.
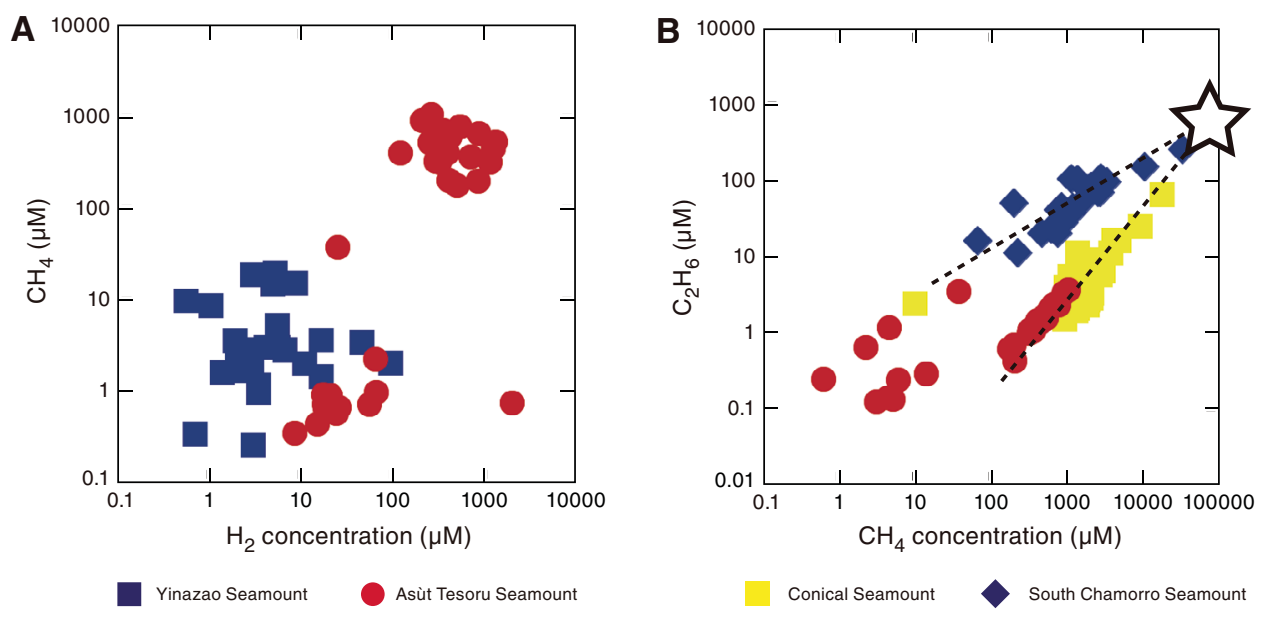

Asùt Tesoru Seamount

Figure F9. Selected interstitial water concentration profiles, Expedition 366. Data for Conical and South Chamorro Seamounts are plotted for comparison to the summit sites (Hulme et al., 2010).
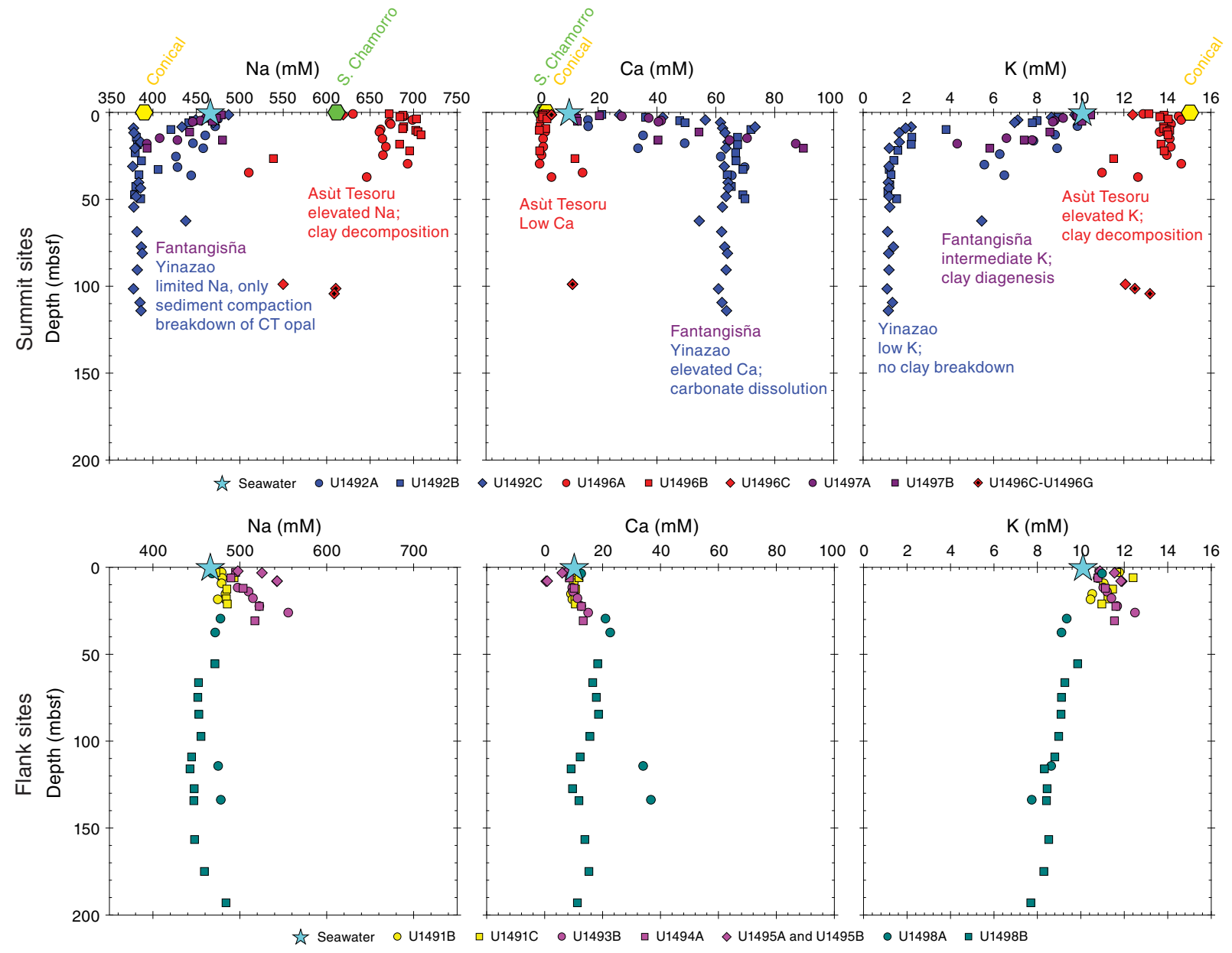
Figure F10. Map of Mariana forearc. Labeled seamounts are active serpentinite mud volcanoes. Shaded regions show where expected reactions are thought to occur within the subduction channel.

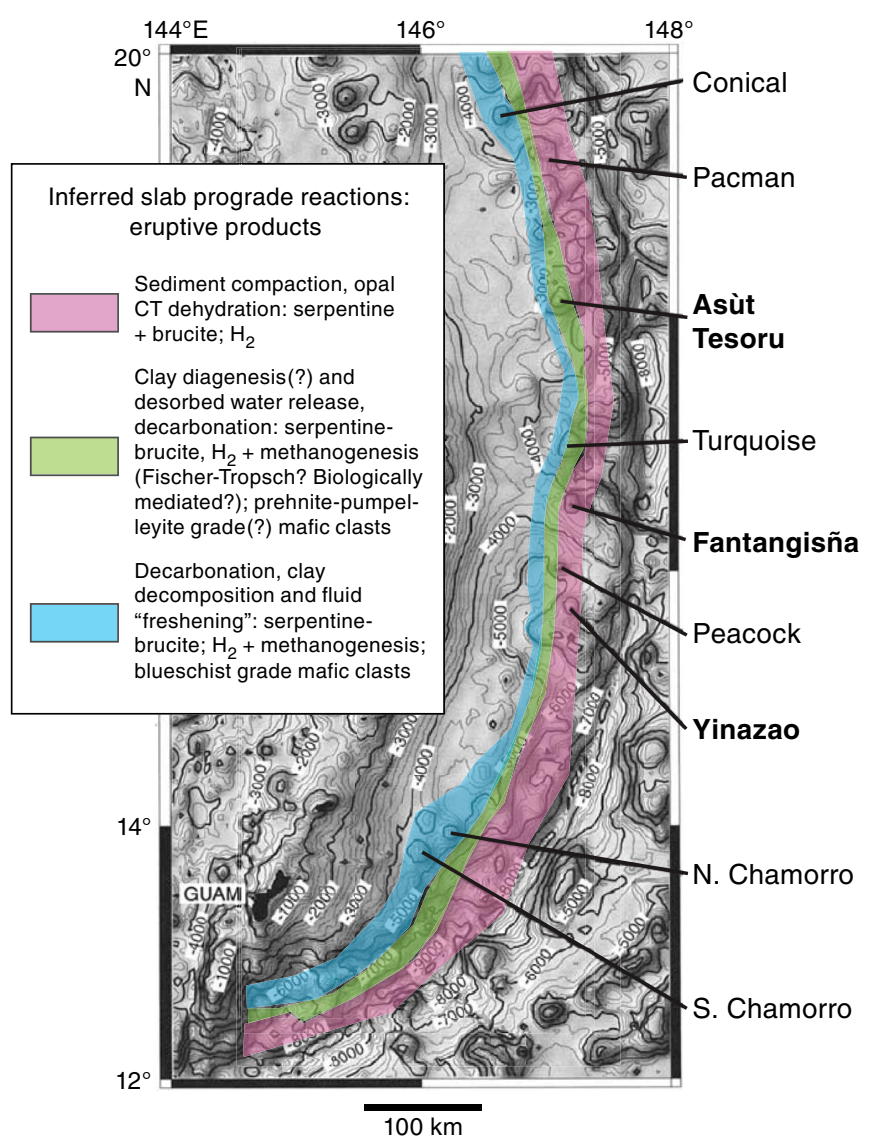


Figure F11. Idealized cartoon of the Mariana forearc with results from interstitial water chemical data derived during Expedition 366 and data from two other serpentinite mud volcanoes at a greater distance from the trench (South Chamorro and Conical Seamounts). Slab devolatilization was identified through the compositions of interstitial water. Interstitial water data for Conical and South Chamorro Seamounts from Hulme et al. (2010). For ease of comparison, all elemental concentrations are plotted in millimolar, but B was multiplied by 10 and Na was divided by 10 for ease of representation. Figure modified from Fryer et al. (1999).

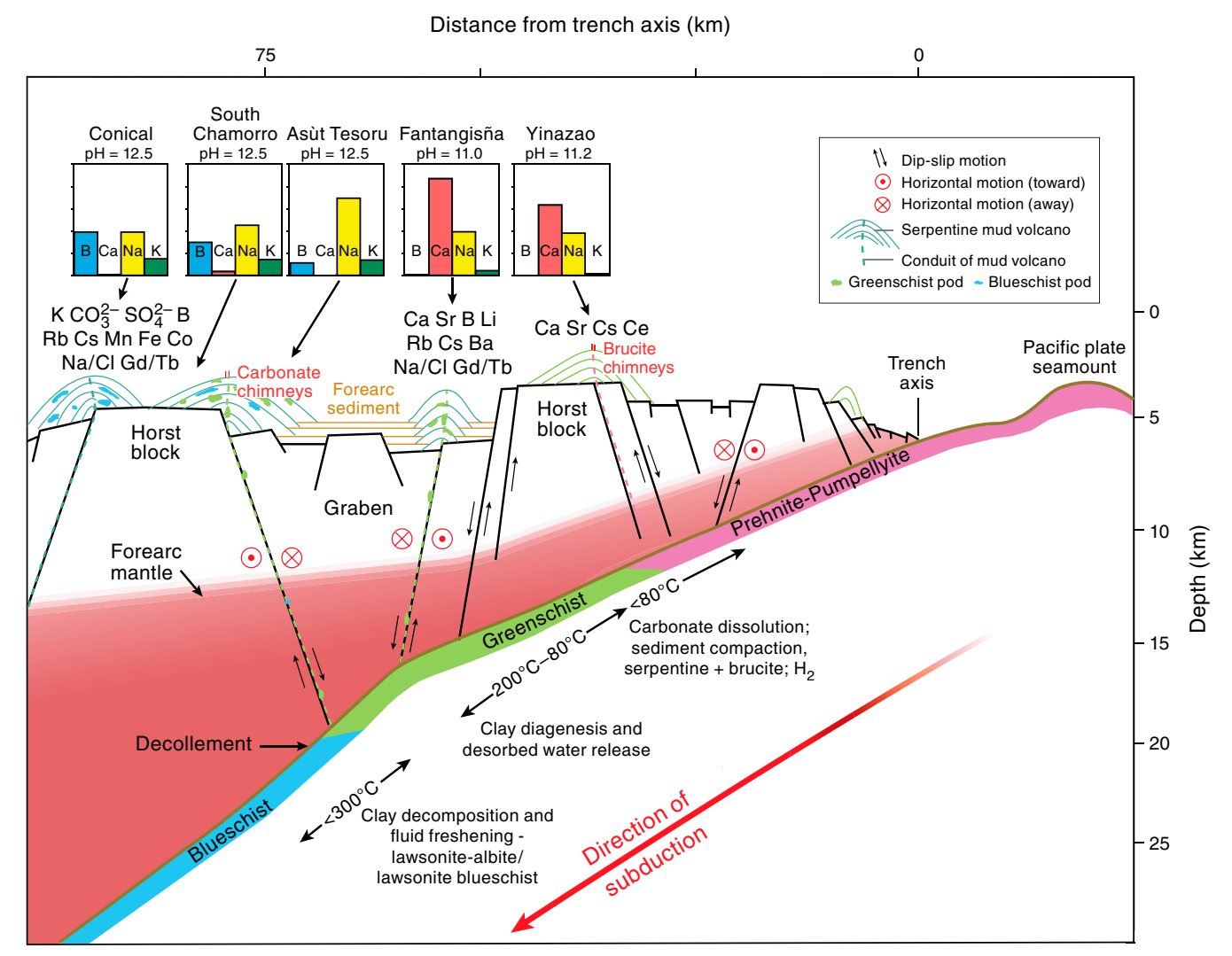

\section{Microbiology}

\section{Sample recovery}

Microbiology sampling during Expedition 366 focused on exploring the limits of microbial life and viral components in serpentinite mudflow habitats across multiple depths using cultivation-based and cultivation-independent molecular biological approaches and microscopy. Sampling efforts targeted both nearsurface and deeper whole-round cores, especially if there was evidence of a transition across gradients of microbiologically affecting compounds and gases (e.g., hydrogen, methane, hydrogen sulfide, and sulfate). Two $20 \mathrm{~cm}$ long whole-round samples were collected at each sampled depth for general microbial analyses (Table T5). Additional whole-round samples were collected for individual investigations. Samples were collected within the context of tracer studies to assess potential contamination resulting from the drilling and sample recovery processes.

Microbiological samples will be analyzed on shore using an array of microbial community-level interrogation techniques. Samples were fixed for total cell counts to quantify microbial biomass. Other samples were maintained at $4{ }^{\circ} \mathrm{C}$ for multiple cultivation techniques (including fluorescence-activated cell sorter [FACS] highthroughput media screening and detection of adaptation to physical parameters such as pressure tolerance). Other samples were flashfrozen at $-80^{\circ} \mathrm{C}$ for molecular analyses, including small-subunit (SSU) ribosomal gene amplicon sequencing (to address community structure in greater detail), functional gene detection and quantifi-
Table T5. Microbiological whole-round samples collected and preserved during Expedition 366. Download table in CSV format.

\begin{tabular}{|c|c|c|}
\hline Seamount & Hole & $\begin{array}{l}\text { Samples } \\
\text { obtained }\end{array}$ \\
\hline \multirow[t]{7}{*}{ Yinazao } & U1491B & 5 \\
\hline & U1491C & 5 \\
\hline & Total: & 10 \\
\hline & U1492A & 9 \\
\hline & U1492B & 12 \\
\hline & U1492C & 16 \\
\hline & Total: & 37 \\
\hline \multirow[t]{9}{*}{ Asùt Tesoru } & U1493B & 5 \\
\hline & U1494A & 7 \\
\hline & U1495A & 2 \\
\hline & U1495B & 2 \\
\hline & Total: & 16 \\
\hline & U1496A & 11 \\
\hline & U1496B & 8 \\
\hline & U1496C & 3 \\
\hline & Total: & 22 \\
\hline \multirow[t]{6}{*}{ Fantangisña } & U1497A & 4 \\
\hline & U1497B & 6 \\
\hline & Total: & 10 \\
\hline & U1498A & 4 \\
\hline & U1498B & 11 \\
\hline & Total: & 15 \\
\hline
\end{tabular}


cation through real-time quantitative polymerase chain reaction (qPCR), and single-cell genomics (to specifically address individual cell contributions). In addition, metagenomics of the entire microbial community and metatranscriptomics of the most highly expressed genes will be used to establish metabolic potential and deeper ecological and evolutionary relationships. Lastly, samples were preserved for enumerating viral counts and assessing viral diversity.

\section{Contamination testing}

Perfluoromethylcyclohexane (PMCH) was used at the first two sites (U1491 and U1492) and the last site (U1498), and perfluoromethyldecalin (PFMD) was used at the remaining sites (U1493U1497). This split was partially due to tracer availability and partially to our ability to establish proper protocols for both perfluorocarbon tracers (PFTs). Data obtained from PMCH measurements show relatively clean (uncontaminated) drilling by advanced piston corer (APC) and half-length APC (HLAPC) operations at Site U1492. This analysis, however, indicates disturbance in cores and drill fluid intrusion at Site U1498, which was drilled using a rotary core barrel (RCB) technique. Generally, drill fluid intrusion into samples was higher at sites where drilling became difficult and required the use of either extended core barrel (XCB) or RCB drilling.

Analysis of the PFMD data does not provide a distinct quantitative assessment of contamination, unlike the PMCH tracer. PFMD is a relatively new method for contamination tracing, and the results from this expedition strongly reinforce the need for further method development if it is to be used when coring sediment.

\section{Shipboard DNA extraction and qPCR}

Shipboard DNA extraction from serpentinite mud samples was unsuccessful using a standard qPCR protocol (e.g., Lever et al., 2015). Additional analysis shows high adsorption of DNA to serpentinite minerals; thus, improvements in DNA extraction protocols in terms of adsorption prevention will be necessary for further DNA extractions. Performing qPCRs on board the R/V JOIDES Resolution is feasible and can expand the range of available shipboard analyses for future expeditions.

\section{Physical properties}

Among the eight sites that were drilled during Expedition 366, the physical properties obtained at the two summit sites at Yinazao and Asùt Tesoru Seamounts (Sites U1492 and U1496, respectively) are distinct. Physical property values are usually associated with consolidation and compaction of sedimentary deposits (e.g., bulk density, porosity, thermal conductivity, and shear strength); however, data from the two summit sites, at the active spring areas observed from the ROV Jason II, indicate that serpentinite muds at these sites were underconsolidated.

For example, the porosity data collected during Expedition 366 followed two trends (Figure F12). One trend was defined by data from summit Sites U1492 and U1496 and ODP Site 780 (Conical Seamount). At each of these sites, porosity decreases with depth from seafloor values of $60 \%-70 \%$ to values of $45 \%-55 \%$ at $120 \mathrm{mbsf}$. An exponential trend was fit to the Site U1492 data, resulting in an Athy's coefficient (Athy, 1930) of 0.36, indicating that this summit site is slightly underconsolidated (Bekins and Dreiss, 1992). Both sites (U1492 and U1496) are located in areas of fluid discharge where discharge rates exceed $10 \mathrm{~cm} / \mathrm{y}$ (Hulme et al., 2010). These sites targeted our best estimate for the location of the current conduit for fluid and material flow from depth. A slight compaction ef-
Figure F12. Porosity data from Expedition 366 sites with data from Leg 125. Expedition 366 summit sites are plotted in blue, and flank sites are plotted in red. Also shown are porosities from ODP Leg 125 Sites 778 and 779 (flank sites) and 780 (summit site). Green and yellow correspond to sites that differ from common flank or summit values, respectively.

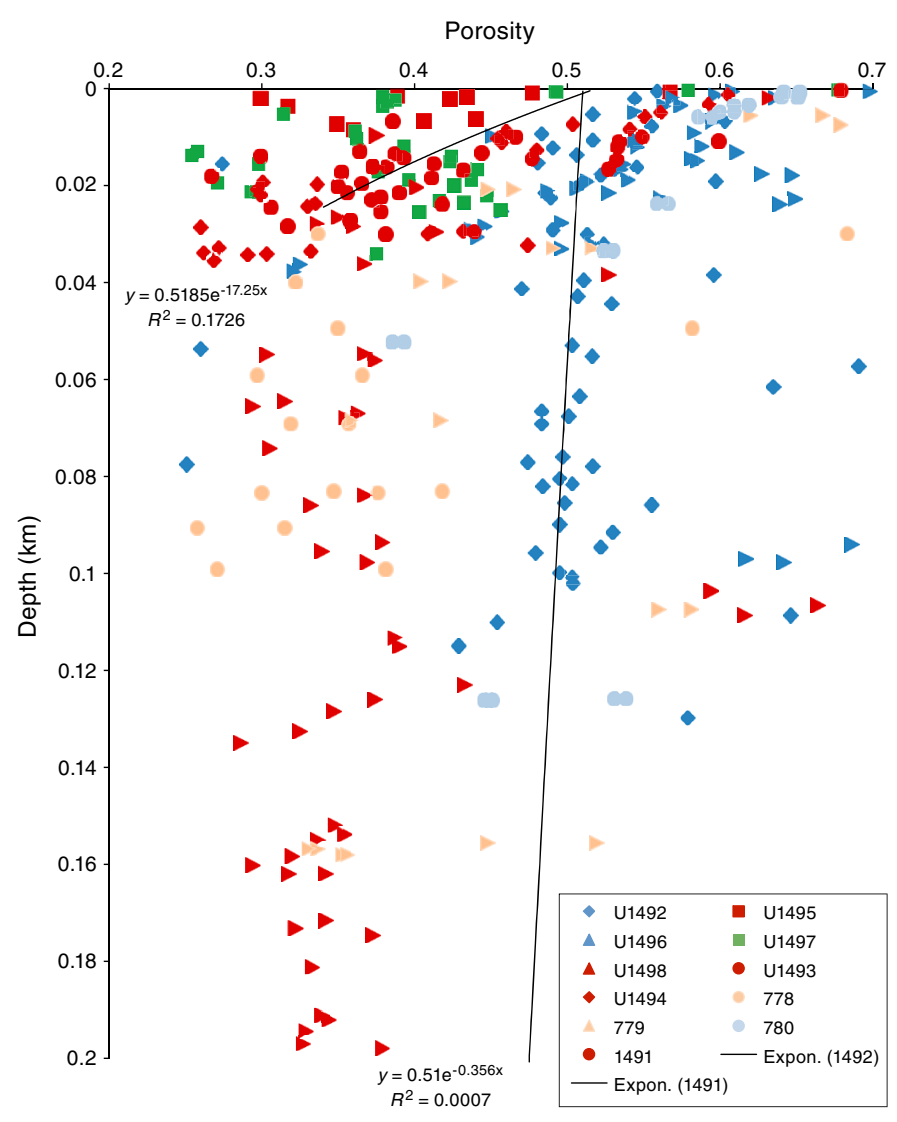

fect is suggested in Holes U1492A and U1492B by the overall increasing trend in gamma ray attenuation (GRA) density with depth, whereas Hole U1492C, the closest one to the presumptive conduit, has lower GRA values and a rather constant trend to the bottom of the hole ( 130 mbsf) (Figure F13). Likewise, consolidation and compaction trends with depth in Hole U1496A at Asùt Tesoru Seamount show a slight increase of bulk density, but no such trend was observed in Hole U1496B. The rather constant GRA bulk density and porosity values observed in Holes U1492C and U1496B, both located less than $20 \mathrm{~m}$ from the presumptive conduit area, appear to be influenced by overpressured fluids localized in the immediate region of the central conduit system, which minimized the compaction of serpentinite mud deposits at these holes. In contrast, GRA density increases in Holes U1492A, U1492B, and U1496A suggest this overpressure effect associated with the conduit system is not effective 50 to $100 \mathrm{~m}$ from the area with the most active fluid discharge. A width of less than $\sim 100 \mathrm{~m}$ for the active conduit at Yinazao and Asùt Tesoru Seamounts is consistent with conduit diameters described for other mud volcanoes, which are considerably smaller than the size of the mud volcanoes themselves (Krastel et al., 2003).

There is a greater decrease in porosity, however, with depth at the other sites (mostly flank sites) to porosity values less than $30 \%$ at only 40 mbsf. The Athy coefficient fit at Site U1494, for example, is 17.3-unreasonably high for a compaction trend. Below 40 mbsf, 
Figure F13. GRA density. A. Holes U1492A-U1492C. Data obtained below 100 mbsf are not plotted. B. Holes U1496A and U1496B.

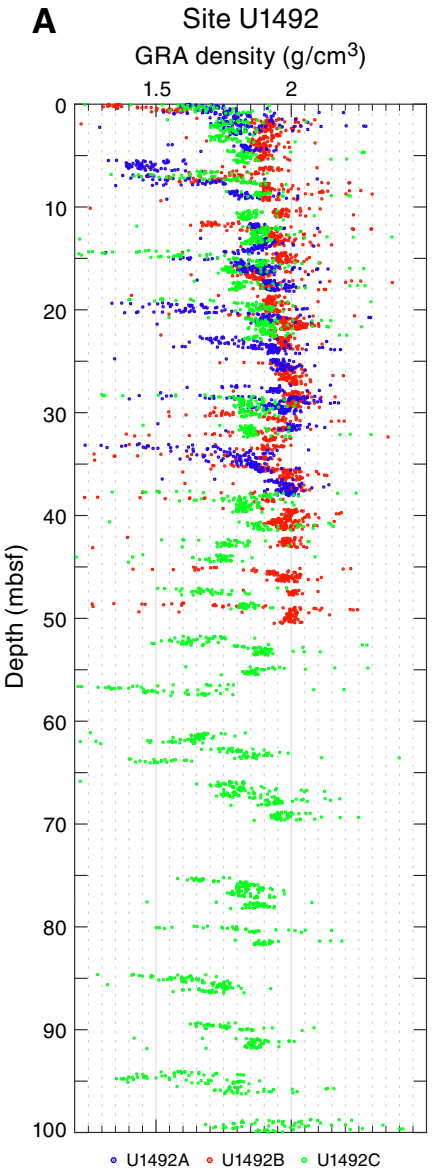

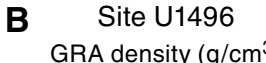

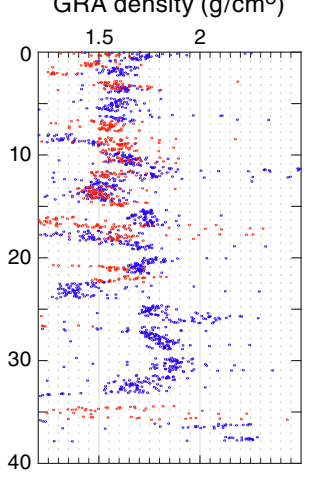

- U1496A - U1496B

porosity values stabilize and remain fairly constant with depth. Such low porosities (and high Athy coefficients) are suggestive of processes other than compaction being responsible for the observed data.

Although similar, there are slight peculiarities in data from the other sites. Even the two sites located on the edge of seamount summits, Sites U1495 and U1497, show behavior more typical of flank sites. The porosity trend at Site U1495 resembles that at flank sites on other seamounts but is more extreme, decreasing from $57 \%$ to $36 \%$ at only 4 mbsf.

The third summit site (Site U1497 on Fantangisña Seamount) is distinct from the other two summit sites. The porosity trend with depth is comparable to those described for the other flank sites (Figure F12). These trends suggest that either the mud volcano has not been active recently or subsurface flow in this area was either diffuse, compartmentalized, and not necessarily vertical or was following trends in local faults associated with the slump features at the summit.

\section{Downhole measurements}

Temperature measurements using the advanced piston corer temperature tool (APCT-3) were attempted 14 times, resulting in 11 records that were used to estimate formation temperatures. These estimates were combined with measured seafloor temperatures and thermal conductivities from collected cores to calculate heat flow for the three summit sites and two of the flank sites (Table T6). The summit heat flow values range from 16.8 to $17.8 \mathrm{~mW} / \mathrm{m}^{2}$, whereas

Table T6. Gradient, thermal conductivity, and heat flow. Download table in CSV format.

\begin{tabular}{|c|c|c|c|c|}
\hline Site & Seamount & $\begin{array}{l}\text { Gradient } \\
\left({ }^{\circ} \mathrm{C} / \mathrm{km}\right)\end{array}$ & $\begin{array}{l}\text { Thermal } \\
\text { conductivity } \\
(\mathrm{W} /[\mathrm{m} \cdot \mathrm{K}])\end{array}$ & $\begin{array}{r}\text { Heat flow } \\
\left(\mathrm{mW} / \mathrm{m}^{2}\right)\end{array}$ \\
\hline \multicolumn{5}{|l|}{ Summits } \\
\hline $1492 C$ & Yinazao & 12.0 & 1.41 & 16.9 \\
\hline $1496 \mathrm{~A}$ & Asùt Tesoro & 14.2 & 1.25 & 17.8 \\
\hline $1497 \mathrm{~A}$ & Fantangisña & 11.7 & 1.43 & 16.8 \\
\hline $1200 A \& E$ & Chamorro & 10.9 & 1.38 & 15.3 \\
\hline \multicolumn{5}{|l|}{ Flanks } \\
\hline 1491B & Yinazao & 20.6 & 1.48 & 30.5 \\
\hline 1493B & Asùt Tesoro & 26.5 & 1.51 & 40 \\
\hline \multicolumn{5}{|c|}{ Sedimentary basin DSDP Leg 60} \\
\hline 459 & Asùt Tesoro & 28.6 & 1.09 & 31.2 \\
\hline 458 & Asùt Tesoro & 25.9 & 1.12 & 29.0 \\
\hline \multicolumn{5}{|c|}{ Sites with flow } \\
\hline $1200 \mathrm{~F}$ & Chamorro & 72.4 & 1.38 & 101 \\
\hline $1492 C$ & Yinazao & 39.8 & 1.41 & 56 \\
\hline 780 & Conical & 37.8 & 1.38 & 52 \\
\hline
\end{tabular}

Figure F14. Calculated heat flow, Expedition 366. Values are derived from downhole APCT-3 formation temperatures and core-based thermal conductivity measurements. Published heat flow data from the area and similar geologic settings are shown for comparison.

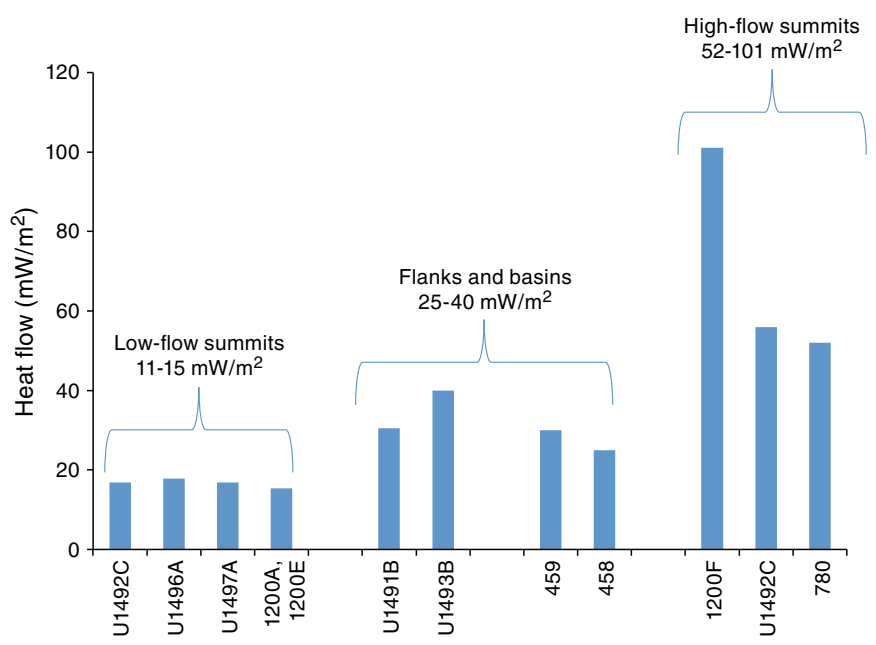

the two flank sites range from 30.5 to $40.0 \mathrm{~mW} / \mathrm{m}^{2}$ (Figure F14). These values and differences are consistent with data from the summit of South Chamorro Seamount, which average $15 \mathrm{~mW} / \mathrm{m}^{2}$ in ODP Holes 1200A and 1200E (Shipboard Scientific Party, 2002), and those collected on the flanks of Conical Seamount at DSDP Sites 458 and 459 (Uyeda and Horai, 1982).

Wireline logging was conducted in Hole U1498B after penetrating to $260 \mathrm{mbsf}$. The triple combo tool string was used to measure magnetic susceptibility, natural gamma radiation (NGR), electrical resistivity, borehole diameter, and temperature of borehole fluids. The downhole logging data show excellent agreement with the shipboard data. The NGR data are consistent with $9 \mathrm{~m}$ of pelagic sediment at the sediment/water interface that was not recovered during coring operations and registered the cherty limestone and metabasalt units. Two possible layers of pelagic sediments, one each at 118 and 137 mbsf intercalated within the serpentinite (e.g., pale streaks in intervals 366-U1498B-13R-4, 21-25 cm, and 15R-3, 6-10 $\mathrm{cm})$. Here, peaks in NGR values are at similar levels to those of Unit 
Figure F15. Magnetic susceptibility and magnetic intensity of the uppermost $40 \mathrm{~m}$ after $20 \mathrm{mT}$ AF demagnetization, Expedition 366 . All sites are included except Site U1495, which penetrated to only 10 mbsf. High magnetic intensity relative to magnetic susceptibility in some cores and holes is likely due to drill string overprint. Asùt Tesoru holes have a higher average susceptibility than the other mud volcanoes.

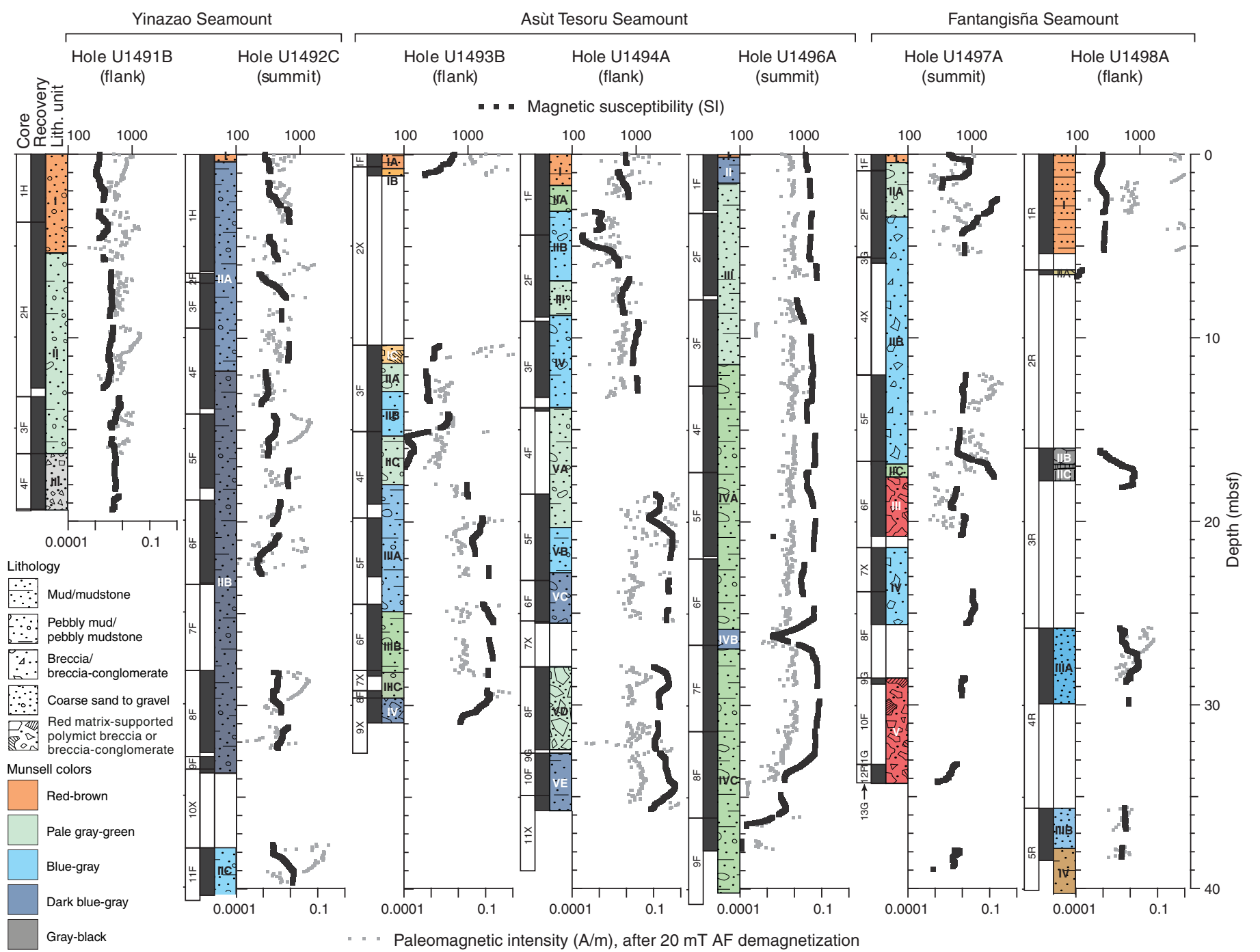

I, presumable ash-rich pelagic sediments that are thought to exist in the upper $9 \mathrm{~m}$ of Hole U1498A. Additional evidence for layers of pelagic sediment is the lack of evidence in the resistivity data for clasts. The resistivity data were useful for detecting large clasts.

\section{Paleomagnetism}

The new 2G Enterprises superconducting rock magnetometer (SRM; liquid helium free) was installed at the start of Expedition 366. Paleomagnetic analyses of archive halves and representative discrete samples were performed. The natural remanent magnetization (NRM) of almost all section halves was measured at $5 \mathrm{~cm}$ intervals after $0,5,10,15$, and $20 \mathrm{mT}$ alternating field (AF) demagnetization steps. The use of principal component analyses provided consistent NRM inclination and declination values between section halves and discrete samples.

A pervasive vertical magnetic overprint was imparted to the cores, likely by the drilling process. In some cases, overprinting was largely demagnetized by AF demagnetization in peak fields of $5 \mathrm{mT}$; in many intervals, however, enough of the overprint remains after the $20 \mathrm{mT}$ demagnetization step that inclination values remain anomalously high. The axial dipole inclination was expected to be between $29.5^{\circ}$ and $33.2^{\circ}$ at the latitude $\left(15.8^{\circ}-18.1^{\circ} \mathrm{N}\right)$ of coring operations. We searched for paleomagnetic reversals for magnetostratigraphic dating in the volcanic ash-rich pelagic sediments that overlie the serpentinite muds, but no clear reversals were found. In some cores, a particularly high intensity overprint was observed between 3 and $5 \mathrm{~m}$ above the base of the core, for example, Cores 366U1492C-5F and 8F (Figure F15).

Magnetic susceptibility levels are generally high, reflecting the high concentrations of magnetic minerals, particularly magnetite, in the cores. Magnetite was of interest because it was produced during serpentinization reactions, to a greater or lesser extent depending on the iron content of the initial minerals. Magnetic susceptibility is higher at the Asùt Tesoru sites, averaging over $1000 \times$ $10^{-5}$ SI compared to the other two mud volcanoes (Figure F15). There is some local correlation between magnetic susceptibility levels and the color of the serpentinite mud, but no correlation across all of the sites. In Hole U1496A, for example, the darker mud between 26 and 27 mbsf has five times lower susceptibility than the surrounding pale green serpentinite mud, whereas in Hole U1493B, 
the pale green serpentinite mud at 20-23 mbsf has much lower susceptibility than the blue-gray mud above and below it.

Magnetic intensities are high, given the high concentrations of magnetic minerals, but there is an unexpectedly large range of intensity values (Figure F15). At Site U1496, the paleomagnetic intensity is relatively low and correlates with magnetic susceptibility, as expected from a consistent lithology and magnetization process. At other sites, however, magnetic intensity is relatively high compared to magnetic susceptibility, and the correlation between the two is less clear, perhaps due to the difficulty in demagnetizing the variable overprint in many of these cores. NRM intensity generally ranges from $1.0 \times 10^{-3}$ to $1.0 \mathrm{~A} / \mathrm{m}$, reaching maximum values of 10 $\mathrm{A} / \mathrm{m}$ in Hole U1494A in dark bluish gray serpentinite pebbly mud. Generally, ultramafic rock clasts present relatively high values of both magnetization and bulk magnetic susceptibility in discrete samples.

\section{Cased borehole operations and results}

Each of the four serpentinite mud volcanoes visited during Expedition 366 (Yinazao, Fantangisña, Asùt Tesoro, and South Chamorro Seamounts) included a borehole operational component. The goal was to deploy an infrastructure that intersected an active hydrologic flow of deep-sourced fluid along a continuum of conditions across the forearc. These boreholes include screened sections to allow formation fluids to enter and are designed for future deployments of CORK-Lites (Wheat et al., 2012). This construct will enable the community to use the boreholes for scientific endeavors, including but not limited to monitoring physical and chemical changes, in situ passive experimentation, and manipulative experiments to address a range of potential scientific questions that center on geophysical, geochemical, and/or microbial studies. A CORK-Lite has a modular design that includes multiple ports for experiments and sensors inside or outside of the CORK body and for large-diameter $(25 \mathrm{~cm})$ experiments and sensors to be deployed within the boreholes, which can be either sealed or allowed to discharge.

\section{South Chamorro Seamount (Site 1200)}

Given the limitations of the original-style CORK that was deployed at Site 1200 during Leg 195, the plan was to remove the CORK body, thus leaving the hole open for a future ROV deployment of a CORK-Lite (Wheat et al., 2012). While attempting to remove the CORK body, the latch rods failed to remove the portion of the CORK that latches into the casing hanger, forming a seal and focusing discharge up a steel pipe that contains the seal sleeve. This steel pipe parted above the seal sleeve. However, the CORK is likely sealed with access to the underlying casing via a portion of a PVC insert that was deployed in 2009, providing a conduit for future sampling activities. The recovered CORK body included white and reddish material on the outside that was collected for microbial and mineralogical analyses. About seven limpets also were recovered from the CORK body and preserved for shore-based identification.

\section{Yinazao (Site U1492), Fantangisña (Site U1497), and Asùt Tesoro (Site U1496) Seamounts}

A casing string was deployed after an initial hole was drilled into the summit region at Yinazao, Fantangisña, and Asùt Tesoro Seamounts. The casing string included at least three joints of screened casing, placing the screened casing as deep as possible and well be- low the near-surface microbial "transition" layer (e.g., Mottl et al., 2003). Difficulties experienced during the deployment of the first casing string changed the depth and design of the second and third deployments.

The initial borehole casing string was deployed at Site U1492. This casing string was $211 \mathrm{~m}$ long with a screened section at 153199 mbsf. The other two casing strings were shorter ( 110 m long) with screened sections at $\sim 35-70$ mbsf. A cement plug was deployed at the base of each of the three casing strings because of a failure during the deployment of a mechanical bridge plug at Site U1492; however, later operations did break the bridge plug free so the base of the casing string could be cemented. These cementing operations were important because serpentinite material flowed into the base of the casing string at Site U1496 within hours of landing the casing within the casing hanger, filling the bottom $7 \mathrm{~m}$ of the open cased hole. We returned to two of the three boreholes (Sites U1496 and U1497) to check the status of the cement and collect a water sample with the water-sampling temperature probe (WSTP) within these two boreholes. We did not have time to return to the cased borehole at Site U1492 after cementing operations.

The cement plug was reached at both sites (U1496 and U1497) several days after cementing operations. The cement was in place as planned and likely sealed the boreholes from intruding material. Water samples were collected from the middle of the upper screened casing joint at both sites. Analysis of this water indicates a mixture of seawater and formation fluid. The Site U1496 sample includes the highest dissolved gas measurements made during the expedition, highlighting the importance of sampling formation fluids directly, thus without the artifacts induced by the coring and sample handling process.

Each of the three new boreholes tapped an active hydrologic zone with formation fluids that discharge into the casing and vent at the seafloor. By deploying a CORK-Lite with an ROV, the community will be able to collect pristine fluids (especially dissolved gases) that are unaffected by sampling artifacts. The community will also be able to collect and/or filter tens to thousands of liters of formation fluid for chemical, microbial, and viral analyses, volumes that are not possible to obtain during standard IODP coring operations. The deployment of CORK-Lites also opens the cased boreholes to a range of sensors, samplers, and experiments that will allow scientists to build a network of borehole observatories, monitoring, and manipulations at the seafloor or within the borehole and with the boreholes sealed or open to discharge.

\section{Preliminary scientific assessment}

Expedition 366 successfully cored the flanks and summit regions of three Mariana forearc serpentinite mud volcanoes, each located at varying depth to the subducting Pacific plate, to characterize processes associated with the formation and activity of these mud volcanoes. The expedition was designed to examine subduction-related processes in terms of the relationship between geochemical cycling, seismicity, and deep biosphere activity in subduction zones and in the lithosphere of the subducting plate. The intent of the expedition was to address how these processes vary spatially along the strike of the Mariana system and with depth to the subduction channel ( 13 to $19 \mathrm{~km}$ below). The results from this expedition complement those from previous Legs 125 and 195 at two other serpentinite mud volcanoes, Conical and South Chamorro Seamounts, both farther from the trench than the three edifices cored during Expedition 366. 
Previous drilling during Leg 125 used rotary coring, and poor recovery failed to provide much of the mudflow matrix in which the rock clasts were entrained. Leg 195 used APC/XCB coring and recovered many thin mudflows, some with more than $100 \%$ recovery, because the matrix contained gases that expanded upon recovery. During Expedition 366, all three coring systems were used, each for a specific purpose. Drilling results during Legs 125 and 195 proved that the mudflows contain, in part, materials from the subduction channel below the edifices. Expedition 366 recovered a greater diversity of subduction channel material from closer to the Mariana Trench, thus from shallower depth-to-slab than material recovered in the two previous legs. Rock clasts and matrix muds from the serpentinite flows recovered during Expedition 366 provide a far better view of the regional processes that have affected the forearc. Furthermore, the cased holes with screened sections that were drilled into the summit regions of these three mud volcanoes now constitute the first regional laboratory for monitoring subduction-related phenomena in the trench-proximal region of a nonaccretionary, intraoceanic, convergent plate margin.

We achieved or will achieve with shore-based analyses all four of the overarching scientific goals outlined in the Expedition 366 Scientific Prospectus. These goals were to assess (1) mass transport processes in the Mariana forearc region, (2) spatial variability of slab-related fluids, (3) metamorphic and tectonic history and physical properties of the subduction zone, and (4) biological activity associated with deep-derived subduction zone material. Associated with these four scientific goals are nine specific objectives, described below.

1. Core mudflows on the flanks of each mud volcano and recover conduit muds from areas near active springs on the summit of each mud volcano.

This objective allowed us to address both construction history and transport processes. We recovered serpentinite mudflows with variable characteristics on the flank of each edifice from Sites U1491 (Yinazao Seamount), U1493, U1494, U1495 (Asùt Tesoru Seamount), and U1498 (Fantangisña Seamount). The serpentinite mudflow matrix varies in color with depth, and although it was distinctly disturbed by flow-in during $\mathrm{APC}$ and XCB coring, it does preserve discrete horizons of clast content and matrix constituents. The cause of the color change in the serpentinite muds is not obvious and will become the focus of several proposed shore-based studies. Although we were without X-ray diffraction or X-ray fluorescence instruments during Expedition 366, samples analyzed with a pXRF and ICP-AES showed essentially no difference in the major elements between the compositions of the serpentinized rock clasts and muds from seamount to seamount, except for specific major and trace elements that are sensitive to redistribution by fluid-rock exchange processes. The latter elements showed more variable patterns in the matrix and fluid data, indicating a regional consistency with depth-to-slab. Expedition 366 results confirm the broad interpretation of gravity core, piston core, and submersible/ROV push core work over the past decade that revealed a regional gradient in terms of change in the composition of slab-related fluids with depth to the subduction channel, as recorded by the fluids discharging from active springs in serpentinite mud volcanoes. The enhancement of this finding as a result of Expedition 366 was that the source of most of the fluids is initially prehnite-pumpellyite facies dehydration followed by greenschist alteration and lastly blueschist dehydration and mobilization of fluid mobile elements. For example, boron and potassium data show drastic increases in the concentration in muds and fluids with distance from the trench.
There remain questions regarding the eruptive processes. Such questions would be better addressed through monitoring. For example, how variable are the volumes of erupted materials, how does the rate of fluid discharge and the stress field change during active episodes of eruption, and what controls the eruptive cycle? The planned CORK-Lite installations at the cased boreholes will be instrumental in addressing temporal-related questions.

\section{Date discrete mudflows paleontologically, should there be sedi- ment layers between them.}

Dating discrete layers will better our understanding of the episodicity of the eruptions and how differences among episodes may affect transport processes. Dating will be possible because we recovered pelagic sediment overlying flank serpentinite mudflows and were able to penetrate the underlying forearc sediments at two of the holes on Fantangisña Seamount's flank. We recovered interlayered mudflows of clay-sized serpentinite mud of a wide variety of oxidized and unoxidized material, as well as interlayered pelagic sediments on the distal edges of Fantangisña Seamount. Very few rock clasts were found in these mudflows. Also, beneath the serpentinite on Fantangisña Seamount, we recovered ash-rich sediment with abundant microfossils. Biostratigraphic ages for the recovered sediments will be determined on shore. The recovery of this material is reminiscent of that in the deepest sediment interval (near Eocene igneous basement) in Hole 459 (Leg 60), which is located south of Asùt Tesoro Seamount (Despraires, 1982).

\section{Determine variability in the composition of rock clasts in the mudflows.}

The anticipated discovery of subduction channel physical and compositional properties was realized through the recovery of numerous rock clasts. Peridotite rock clasts were present in the cores from each of the three seamounts that were drilled. They include dunites, harzburgites, and pyroxenites and vary in degree of serpentinization from $30 \%$ to $100 \%$. The less serpentinized peridotites preserve relict olivine and orthopyroxene that will make it possible to use crystal preferred orientation analysis to study the history of stress distribution, both across- and along-strike of the entire southern Mariana suprasubduction-zone mantle wedge. Cores from the flanks of the mud volcanoes included microfossils in some mudflow intervals and beneath the distal flank of Fantangisña Seamount. Paleontologic age ranges from these will be determined to constrain temporal aspects of the history of mantle stress patterns.

We also discovered striking variability in the lithology of other rock clasts within the mudflows, and the results of shipboard observations and analysis show that all five of the serpentinite seamounts cored to date (including Leg 125 and 195 cores) contain lithologies from the subducted slab. The fact that all of these mud volcanoes tapped slab-derived fluids and erupt rock clasts from the subduction channel confirms that these edifices are indeed natural windows to slab processes. The range of recovered material from Expedition 366 is particularly illuminating because we recovered fosilliferous reef limestones and metavolcanics with alkalic provenance, as well as compositions consistent with ocean island basalts. These lithologies indicate a source from subducted Pacific plate and seamounts on it.

Also collected were clasts that span the entire range of lithospheric compositions known to have formed in the suprasubduction-zone region of the Mariana forearc crust. Thus, Expedition 366 results also confirm that serpentinite mud volcanoes erupt the entire suite of rock materials that represent the subsurface architecture of the Mariana arc. The fact that the mud 
volcanoes occur exclusively in association with forearc scarps suggests that vertical tectonism of the forearc is the rule rather than the exception.

4. Study potential systematic variability in the degree of serpentinization of rock clasts and distinguish the characteristics of the mudflow matrix on the flanks from those in the summit conduit regions.

Coring on the flanks of the edifices revealed for the first time that there is systematic increase in the degree of serpentinization of rock clasts and of secondary mineralization of the mudflow matrix with increasing depth down the flanks of the mud volcanoes. Most ultramafic clasts recovered from the flanks reacted to a greater extent with muds that are generally $100 \%$ serpentinized. Furthermore, individual serpentinized rock clasts are soft enough to indent with a fingernail. Reaction of the clasts with the matrix muds is evident where halos surround clasts and darken the adjacent mud. The degree of serpentinization in ultramafic clasts is variable in the summit regions, where episodicity of activity in the conduits of these edifices may cause pulsing, presumably on various timescales, of the mud matrix and fluids and may refresh the throat with new and less reacted materials.

\section{Examine transport conditions of muds and interstitial waters on the seamount flanks.}

Transport conditions of muds and interstitial waters are remarkably variable on the flanks and in the summit regions of the seamounts. Changes in the density and porosity of mudflows on the flanks of the seamounts indicate that compaction is not the only force that affects trends in these physical properties with depth. Additionally, deformation by gravitational sliding (Oakley et al., 2007) may affect these profiles, as can continued serpentinization and alteration to other phases that significantly reduce porosity. Causes for these changes in physical properties will be assessed in shorebased mineralogical analysis and rheologic studies of whole-round samples. The latter were collected and preserved for mechanical, stress, and permeability testing, including the determination of physical properties.

6. Provide a measure for comparing the nature of hydrologic characteristics (e.g., diffuse versus channelized fluid flow) on the flanks and summit regions of the mud volcanoes.

Systematic variations in interstitial water composition profiles from flank sites indicate no significant vertical discharge of fluids. At each of the summit sites, interstitial water compositions show clear evidence of seepage at discharge rates in excess of the serpentinite matrix, which also is ascending and constructing the dome-like features on the summit of two of the three seamounts that were cored. These results are consistent with published data that define the range and area of discharge at the summit sites.

\section{Determine the composition of fluid from depth and assess the type, extent, and effect of diagenetic reactions that occurred on the flanks of serpentinite mud volcanoes.}

Systematic variations in interstitial water composition profiles from Yinazao (13 km depth-to-slab), Fantangisña (14 km), and Asùt Tesoru $(18 \mathrm{~km})$ Seamounts augment previous results from South Chamorro (18 km) and Conical (19 km) Seamounts (Table T1). This combination of data extends the dramatic change, noted in previous studies (Mottl et al., 2004; Hulme et al., 2010), in the compositions of the slab-derived serpentinizing fluids as the subduction channel deepens. Dramatic differences include elevated $\mathrm{Ca}$ and $\mathrm{Sr}$ and low to extremely low $\mathrm{K}, \mathrm{Na}, \mathrm{Cl}, \mathrm{SO}_{4}, \mathrm{~B}$, and $\mathrm{Na} / \mathrm{Cl}$ in fluids from Yinazao Seamount and, to a lesser extent, Fantangisña Seamount. In contrast, discharging fluids from Asùt Tesoru Seamount have a composition similar to that from South Chamorro and Conical Seamounts, with extremely high $\mathrm{pH}$ (up to 12.48), $\mathrm{Ca}$ and $\mathrm{Sr}$ depletions, and marked enrichments in carbonate alkalinity, DIC, DOC, $\mathrm{NH}_{4}, \mathrm{Na}$, $\mathrm{K}, \mathrm{Na} / \mathrm{Cl}$, and $\mathrm{B}$. Na concentrations are higher at Asùt Tesoru Seamount than at any the five seamounts mentioned above. Chemical compositions of interstitial water from the flank sites are consistent with a mixture of slab-derived fluid and seawater. Superimposed on this mixture are diagenetic changes that are evident in some of the measured chemical species.

Coupled to the seventh objective was the desire to document the composition of dissolved gases, specifically $\mathrm{H}_{2}, \mathrm{CH}_{4}$, and $\mathrm{C}_{2} \mathrm{H}_{6}$. Compositions of these gases differed from site to site, providing a measure of deep-sourced fluid composition. High concentrations of $\mathrm{H}_{2}, \mathrm{CH}_{4}$, and $\mathrm{C}_{2} \mathrm{H}_{6}$ were observed at the summit of Asùt Tesoru Seamount, and comparatively low but significant levels were detected at both summit and flank sites at Yinazao Seamount. Concentrations of $\mathrm{H}_{2}$ and $\mathrm{CH}_{4}$ show two distinct groupings: serpentinizationdriven $\mathrm{H}_{2}$ production and methane production. The relationship between methane and ethane data from Asùt Tesoru, South Chamorro, and Conical Seamounts converge on a single composition that may represent the hydrocarbon values produced by abiotic (Fisher Tropsch Type) synthesis in the deep-sourced fluid.

\section{Collect samples for the study of microbial/viral community inter- actions in materials bathed in deep-sourced fluids, distal ser- pentinite mud flows, and the underlying forearc pelagic sediment.}

Whole-round samples collected for microbiological studies were subsampled for shore-based analyses to explore the limits of microbial life in serpentinite mud using cultivation-based and cultivation-independent molecular biological approaches, microscopy, and assays for the detection of viruses. Postexpedition analyses will include an array of microbial community-level interrogation techniques: (1) total cell counts to quantify microbial biomass; (2) cultivation (including FACS high-throughput media screening and detection of adaptation to physical parameters such as pressure tolerance); (3) molecular analyses, including SSU ribosomal gene amplicon sequencing (to address community structure in greater detail), functional gene detection, and quantification through qPCR and single-cell genomics (to specifically address individual cell contributions); (4) metagenomics of the entire microbial community and metatranscriptomics of the most highly expressed genes to establish metabolic potential and deeper ecological and evolutionary relationships; and (5) viral counts and diversity. The only microbial analysis conducted at sea was to assess the quality of the whole rounds via tracer analysis. Tracers were pumped into the drill string prior to and during core recovery. Systematic sampling of the cored material and overlying surficial fluids indicates that most of the whole-round samples for microbiology are suitable for continued shore-based analyses.

\section{Complete initial fabrication of borehole structures for future in situ experiments and observations.}

Three casing strings, each with three or more joints of screened casing, were deployed, one in each of the summits of the cored serpentinite mud volcanoes. These casing strings form the foundation for a future deployment of CORK-Lites (Wheat et al., 2012), which allow for a range of experiments and observations to be conducted 
simultaneously within a single structure that is open to deepsourced fluids. We collected a water sample and measured temperature within two of the three newly deployed cased boreholes days after the bottom was sealed with cement. The recovered fluids were a mixture of seawater (drilling fluids) and deep-sourced fluid, and temperatures were higher than expected based on measurements collected during serpentinite mud coring operations. Combined, these data indicate that both boreholes tapped a hydrologic zone and active fluid discharge exists. The third site also should have active discharge based on systematic variations in interstitial water composition profiles that indicate fluid discharge rates of centimeters to tens of centimeters per year in the summit area. Similar results were observed at South Chamorro Seamount, which supports a CORK (Hole 1200C) with active fluid discharge. During Expedition 366, we visited Hole $1200 \mathrm{C}$ to remove the CORK body. Most of the CORK body from Hole $1200 \mathrm{C}$ was removed, leaving the sleeve joint that allows access to the CORK, but it retains the 3.25 inch diameter. Thus, with future funding and ROV operations, a network of four cased borehole observatory systems will exist that span a range of distances from the trench, representing a variety of pressure and temperature conditions at depth and different compositions of deep-sourced fluids. Such a transect will be instrumental to in situ experimentation and future monitoring for the study of, for example, processes associated with material (e.g., rocks, fluid, and mud) flow and alteration (e.g., abiotic and biotic reactions).

\section{References}

Athy, L.F., 1930. Density, porosity, and compaction of sedimentary rocks. AAPG Bulletin, 14(1):1-24.

Bekins, B.A., and Dreiss, S.J., 1992. A simplified analysis of parameters controlling dewatering in accretionary prisms. Earth and Planetary Science Letters, 10(3-4)275-287. https://doi.org/10.1016/0012821X(92)90092-A

Bhanot, K.K., Downes, H., Petrone, C.M., and Humphreys-Williams, E., in press. Textures in spinel peridotite mantle xenoliths using micro-CT scanning: examples from Canary Islands and France. Lithos. https://doi.org/10.1016/j.lithos.2016.08.004

Curtis, A.C., Wheat, C.G., Fryer, P., and Moyer, C.L., 2013. Mariana forearc serpentinite mud volcanoes harbor novel communities of extremophilic Archaea. Geomicrobiology Journal, 30(5):430-441. https://doi.org/10.1080/01490451.2012.705226

Desprairies, A., 1982. Authigenic minerals in volcanogenic sediments cored during Deep Sea Drilling Project Leg 60. In Hussong, D.M., Uyeda, S., et al., Initial Reports of the Deep Sea Drilling Project, 60: Washington, DC (U.S. Government Printing Office), 455-466. https://doi.org/10.2973/dsdp.proc.60.120.1982

Fryer, P., 2012. Serpentinite mud volcanism: observations, processes, and implications. Annual Review of Marine Science, 4(1):345-373. https://doi.org/10.1146/annurev-marine-120710-100922

Fryer, P., Gharib, J., Ross, K., Savov, I., and Mottl, M.J., 2006. Variability in serpentinite mudflow mechanisms and sources: ODP drilling results on Mariana forearc seamounts. Geochemistry, Geophysics, Geosystems, 7(8):Q08014. https://doi.org/10.1029/2005GC001201

Fryer, P., and Mottl, M., 1997. Shinkai 6500 investigations of a resurgent mud volcano on the southeastern Mariana forearc. JAMSTEC Journal of Deep Sea Research, 13:103-114. http://www.godac.jamstec.go.jp/catalog/data/doc_catalog/media/shinkai13_09.pdf

Fryer, P., Pearce, J.A., Stokking, L.B., et al., 1990. Proceedings of the Ocean Drilling Program, Initial Reports, 125: College Station, TX (Ocean Drilling Program). https://doi.org/10.2973/odp.proc.ir.125.1990

Fryer, P., Wheat, C.G., and Mottl, M.J., 1999. Mariana blueschist mud volcanism: implications for conditions within the subduction zone. Geology, 27(2):103-106. https://doi.org/10.1130/0091-

7613(1999)027<0103:MBMVIF>2.3.CO;2
Fryer, P.B., and Salisbury, M.H., 2006. Leg 195 synthesis: Site 1200-serpentinite seamounts of the Izu-Bonin/Mariana convergent plate margin (ODP Leg 125 and 195 drilling results). In Shinohara, M., Salisbury, M.H., and Richter, C. (Eds.), Proceedings of the Ocean Drilling Program, Scientific Results, 195: College Station, TX (Ocean Drilling Program), 1-30. https://doi.org/10.2973/odp.proc.sr.195.112.2006

Gharib, J., 2006. Clastic metabasites and authigenic minerals within serpentinite protrusions from the Mariana forearc: implications for subforearc subduction processes [Ph.D. dissertation]. University of Hawaii.

Haggerty, J.A., 1991. Evidence from fluid seeps atop serpentine seamounts in the Mariana forearc: clues for emplacement of the seamounts and their relationship to forearc tectonics. Marine Geology, 102(1-4):293-309. https://doi.org/10.1016/0025-3227(91)90013-T

Haggerty, J.A., and Chaudhuri, S., 1992. Strontium isotopic composition of the interstitial waters from Leg 125: Mariana and Bonin forearcs. In Fryer, P., Pearce, J.A., Stokking, L.B., et al., Proceedings of the Ocean Drilling Program, Scientific Results, 125: College Station, TX (Ocean Drilling Program), 397-400. https://doi.org/10.2973/odp.proc.sr.125.124.1992

Haggerty, J.A., and Fisher, J.B., 1992. Short-chain organic acids in interstitial waters from Mariana and Bonin forearc serpentines: Leg 125. In Fryer, P., Pearce, J.A., Stokking, L.B., et al., Proceedings of the Ocean Drilling Program, Scientific Results, 125: College Station, TX (Ocean Drilling Program), 387-395. https://doi.org/10.2973/odp.proc.sr.125.125.1992

Hanson, G.N., and Langmuir, C.H., 1978. Modelling of major elements in mantle-melt systems using trace element approaches. Geochimica et Cosmochimica Acta, 42(6):725-741.

http://dx.doi.org/10.1016/0016-7037(78)90090-X

Hulme, S.M., Wheat, C.G., Fryer, P., and Mottl, M.J., 2010. Pore water chemistry of the Mariana serpentinite mud volcanoes: a window to the seismogenic zone. Geochemistry, Geophysics, Geosystems, 11(1):Q01X09. https://doi.org/10.1029/2009GC002674

Johnson, L.E., and Fryer, P., 1990. The first evidence for MORB-like lavas from the outer Mariana forearc: geochemistry, petrography and tectonic implications. Earth and Planetary Science Letters, 100(1-3):304-316. https://doi.org/10.1016/0012-821X(90)90193-2

Krastel, S., Spiess, V., Ivanov, M., Weinrebe, W., Bohrmann, G., Shashkin, P., and Heidersdorf, F., 2003. Acoustic investigations of mud volcanoes in the Sorokin Trough, Black Sea. Geo-Marine Letters, 23(3-4):230-238. https://doi.org/10.1007/s00367-003-0143-0

Lenoir, X., Garrido, C.J., Bodinier, J.-L., and Dautria, J.-M., 2000. Contrasting lithospheric mantle domains beneath the Massif Central (France) revealed by geochemistry of peridotite xenoliths. Earth and Planetary Science Letters, 181(3):359-375. https://doi.org/10.1016/S0012-821X(00)00216-8

Lever, M.A., Torti, A., Eickenbusch, P., Michaud, A.B., Šantl-Temkiv, T., and Jørgensen, B.B., 2015. A modular method for the extraction of DNA and RNA, and the separation of DNA pools from diverse environmental sample types. Frontiers in Microbiology, 6:1-25. https://doi.org/10.3389/fmicb.2015.00476

Maekawa, H., Shozui, M., Ishii, T., Fryer, P., and Pearce, J.A., 1993. Blueschist metamorphism in an active subduction zone. Nature, 364(6437):520523. https://doi.org/10.1038/364520a0

McCollom, T.M., and Bach, W., 2009. Thermodynamic constraints on hydrogen generation during serpentinization of ultramafic rocks. Geochimica et Cosmochimica Acta, 73(3):856-875. https://doi.org/10.1016/j.gca.2008.10.032

Mercier, J.-C.C., and Nicolas, A., 1975. Textures and fabrics of upper-mantle peridotites as illustrated by xenoliths from basalts. Journal of Petrology, 16(2):454-487. https://doi.org/10.1093/petrology/16.2.454

Mottl, M.J., 1992. Pore waters from serpentinite seamounts in the Mariana and Izu-Bonin forearcs, Leg 125: evidence for volatiles from the subducting slab. In Fryer, P., Pearce, J.A., Stokking, L.B., et al., Proceedings of the Ocean Drilling Program, Scientific Results, 125: College Station, TX (Ocean Drilling Program), 373-385. https://doi.org/10.2973/odp.proc.sr.125.121.1992

Mottl, M.J., and Alt, J.C., 1992. Data report: minor and trace element and sulfur isotopic composition of pore waters from Sites 778 through 786. In Fryer, P., Pearce, J.A., Stokking, L.B., et al., Proceedings of the Ocean Drill- 
ing Program, Scientific Results, 125: College Station, TX (Ocean Drilling Program), 683-688. https://doi.org/10.2973/odp.proc.sr.125.184.1992

Mottl, M.J., Komor, S.C., Fryer, P., and Moyer, C.L., 2003. Deep-slab fluids fuel extremophilic Archaea on a Mariana forearc serpentinite mud volcano: Ocean Drilling Program Leg 195. Geochemistry, Geophysics, Geosystems, 4:9009. https://doi.org/10.1029/2003GC000588

Mottl, M.J., Wheat, C.G., Fryer, P., Gharib, J., and Martin, J.B., 2004. Chemistry of springs across the Mariana forearc shows progressive devolatilization of the subducting plate. Geochimica et Cosmochimica Acta, 68(23):4915-4933. https://doi.org/10.1016/j.gca.2004.05.037

Oakley, A., 2008. A multi-channel seismic and bathymeric investigation of the central Mariana convergent margin [Ph.D. dissertation]. University of Hawaii. http://www.soest.hawaii.edu/GG/resources/theses/Oakley Dissertation 2008.pdf

Oakley, A.J., Taylor, B., Fryer, P., Moore, G.F., Goodliffe, A.M., and Morgan, J.K., 2007. Emplacement, growth, and gravitational deformation of serpentinite seamounts on the Mariana forearc. Geophysical Journal International, 170(2):615-634. https://doi.org/10.1111/j.1365-246X.2007.03451.x

Oakley, A.J., Taylor, B., and Moore, G.F., 2008. Pacific plate subduction beneath the central Mariana and Izu-Bonin fore arcs: new insights from an old margin. Geochemistry, Geophysics, Geosystems, 9(6):Q06003. https://doi.org/10.1029/2007GC001820

Reagan, M.K., Ishizuka, O., Stern, R.J., Kelley, K.A., Ohara, Y., Blichert-Toft, J., Bloomer, S.H., Cash, J., Fryer, P., Hanan, B.B., Hickey-Vargas, R., Ishii, T., Kimura, J.-I., Peate, D.W., Rowe, M.C., and Woods, M., 2010. Fore-arc basalts and subduction initiation in the Izu-Bonin-Mariana system. Geochemistry, Geophysics, Geosystems, 11(3):Q03X12. https://doi.org/10.1029/2009GC002871

Savov, I.P., Guggino, S., Ryan, J.G., Fryer, P., and Mottl, M.J., 2005a. Geochemistry of serpentinite muds and metamorphic rocks from the Mariana forearc, ODP Sites 1200 and 778-779, South Chamorro and Conical Seamounts. In Shinohara, M., Salisbury, M.H., and Richter, C. (Eds.), Proceedings of the Ocean Drilling Program, Scientific Results, 195: College Station, TX (Ocean Drilling Program), 1-49. https://doi.org/10.2973/odp.proc.sr.195.103.2005

Savov, I.P., Ryan, J.G., D’Antonio, M., and Fryer, P., 2007. Shallow slab fluid release across and along the Mariana arc-basin system: insights from geochemistry of serpentinized peridotites from the Mariana fore arc. Journal of Geophysical Research: Solid Earth, 112(B9):B09205. https://doi.org/10.1029/2006JB004749

Savov, I.P., Ryan, J.G., D’Antonio, M., Kelley, K., and Mattie, P., 2005b. Geochemistry of serpentinized peridotites from the Mariana Forearc Conical
Seamount, ODP Leg 125: implications for the elemental recycling at subduction zones. Geochemistry, Geophysics, Geosystems, 6(4):Q04J15. https://doi.org/10.1029/2004GC000777

Shervais, J.W., 1982. Ti-V plots and the petrogenesis of modern and ophiolitic lavas. Earth and Planetary Science Letters, 59(1):101-118. https://doi.org/10.1016/0012-821X(82)90120-0

Shipboard Scientific Party, 1990. Site 780. In Fryer, P., Pearce, J.A., Stokking, L.B., et al., Proceedings of the Ocean Drilling Program, Initial Reports, 125: College Station, TX (Ocean Drilling Program), 147-178. https://doi.org/:10.2973/odp.proc.ir.125.108.1990

Shipboard Scientific Party, 2002. Site 1200. In Salisbury, M.H., Shinohara, M., Richter, C., et al., Proceedings of the Ocean Drilling Program, Initial Reports, 195: College Station, TX (Ocean Drilling Program), 1-173. https://doi.org/10.2973/odp.proc.ir.195.103.2002

Smith, D., 1977. The origin and interpretation of spinel-pyroxene clusters in peridotite. Journal of Geology, 85(4):476-482. https://doi.org/10.1086/628321

Takai, K., Moyer, C.L., Miyazaki, M., Nogi, Y., Hirayama, H., Nealson, K.H., and Horikoshi, K., 2005. Marinobacter alkaliphilus sp. nov., a novel alkaliphilic bacterium isolated from subseafloor alkaline serpentine mud from Ocean Drilling Program Site 1200 at South Chamorro Seamount, Mariana forearc. Extremophiles, 9(1):17-27. https://doi.org/10.1007/s00792-004-0416-1

Uyeda, S., and Horai, K., 1982. Heat flow measurements on Deep Sea Drilling Project Leg 60. In Hussong, D.M., Uyeda, S., et al., Initial Reports of the Deep Sea Drilling Project, 60: Washington, DC (U.S. Government Printing Office), 789-800. https://doi.org/10.2973/dsdp.proc.60.146.1982

Uyeda, S., and Kanamori, H., 1979. Back-arc opening and the mode of subduction. Journal of Geophysical Research: Solid Earth, 84(B3):1049-1061. https://doi.org/10.1029/JB084iB03p01049

Wheat, C.G., Edwards, K.J., Pettigrew, T., Jannasch, H.W., Becker, K., Davis, E.E., Villinger, H., and Bach, W., 2012. CORK-lite: bringing legacy boreholes back to life. Scientific Drilling, 14:39-43. https://doi.org/10.2204/iodp.sd.14.05.2012

Wheat, C.G., Fryer, P., Fisher, A.T., Hulme, S., Jannasch, H., Mottl, M.J., and Becker, K., 2008. Borehole observations of fluid flow from South Chamorro Seamount, an active serpentinite mud volcano in the Mariana forearc. Earth and Planetary Science Letters, 267(3-4):401-409. https://doi.org/10.1016/j.epsl.2007.11.057

Wheat, C.G., Fryer, P., Takai, K., and Hulme, S., 2010. Spotlight 9: South Chamorro Seamount, $13^{\circ} 7.00^{\prime} \mathrm{N}, 146^{\circ} 00.00^{\prime}$ E. Oceanography, 23(1):174175. http://www.tos.org/oceanography/issues/issue_archive/issue_pdfs/23_1/23-1_wheat.pdf 